\title{
Seasonal variations of belowground carbon transfer assessed by in situ ${ }^{13} \mathrm{CO}_{2}$ pulse labelling of trees
}

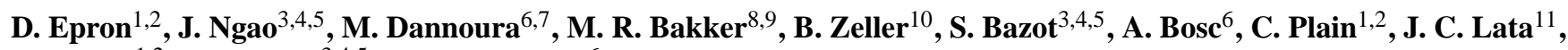 \\ P. Priault ${ }^{1,2}$, L. Barthes ${ }^{3,4,5}$, and D. Loustau ${ }^{6}$ \\ ${ }^{1}$ Université Henri Poincaré, UMR1137, 54500 Vandoeuvre-les-Nancy, France \\ ${ }^{2}$ INRA, UMR1137, Centre INRA de Nancy, 54280 Champenoux, France \\ ${ }^{3}$ Université Paris-Sud, UMR8079, Orsay, 75231 Paris, France \\ ${ }^{4}$ CNRS, UMR8079, Centre de Recherche de Gif, 91190 Gif-sur-Yvette, France \\ ${ }^{5}$ AgroParisTech, UMR8079, 75231 Paris, France \\ ${ }^{6}$ INRA, UR1263, Centre INRA de Bordeaux, 33140, Villenave d'Ornon, France \\ ${ }^{7}$ Kyoto University, Laboratory of Forest Utilization, Kyoto 606-8502, Japan \\ ${ }^{8}$ ENITA de Bordeaux, UMR1220, 33883 Villenave d'Ornon, France \\ ${ }^{9}$ INRA, UMR1220, Centre INRA de Bordeaux, 33883 Villenave d'Ornon, France \\ ${ }^{10}$ INRA, UR1138, Centre de Nancy, 54280 Champenoux, France \\ ${ }^{11}$ UPMC-Paris6, UMR7618, 75230 Paris, France
}

Received: 7 January 2011 - Published in Biogeosciences Discuss.: 2 February 2011

Revised: 7 May 2011 - Accepted: 9 May 2011 - Published: 17 May 2011

\begin{abstract}
Soil $\mathrm{CO}_{2}$ efflux is the main source of $\mathrm{CO}_{2}$ from forest ecosystems and it is tightly coupled to the transfer of recent photosynthetic assimilates belowground and their metabolism in roots, mycorrhiza and rhizosphere microorganisms feeding on root-derived exudates. The objective of our study was to assess patterns of belowground carbon allocation among tree species and along seasons. Pure ${ }^{13} \mathrm{CO}_{2}$ pulse labelling of the entire crown of three different tree species (beech, oak and pine) was carried out at distinct phenological stages. Excess ${ }^{13} \mathrm{C}$ in soil $\mathrm{CO}_{2}$ efflux was tracked using tuneable diode laser absorption spectrometry to determine time lags between the start of the labelling and the appearance of ${ }^{13} \mathrm{C}$ in soil $\mathrm{CO}_{2}$ efflux and the amount of ${ }^{13} \mathrm{C}$ allocated to soil $\mathrm{CO}_{2}$ efflux. Isotope composition $\left(\delta^{13} \mathrm{C}\right)$ of $\mathrm{CO}_{2}$ respired by fine roots and soil microbes was measured at several occasions after labelling, together with $\delta^{13} \mathrm{C}$ of bulk root tissue and microbial carbon. Time lags ranged from 0.5 to 1.3 days in beech and oak and were longer in pine (1.6-2.7 days during the active growing season, more than 4 days during the resting season), and the transfer of $\mathrm{C}$ to the microbial biomass was as fast as to the fine roots. The amount of ${ }^{13} \mathrm{C}$ allocated to soil $\mathrm{CO}_{2}$ efflux was estimated from a compartment
\end{abstract}

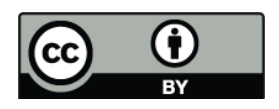

Correspondence to: D. Epron (daniel.epron@scbiol.uhp-nancy.fr) model. It varied between 1 and $21 \%$ of the amount of ${ }^{13} \mathrm{CO}_{2}$ taken up by the crown, depending on the species and the season. While rainfall exclusion that moderately decreased soil water content did not affect the pattern of carbon allocation to soil $\mathrm{CO}_{2}$ efflux in beech, seasonal patterns of carbon allocation belowground differed markedly between species, with pronounced seasonal variations in pine and beech. In beech, it may reflect competition with the strength of other sinks (aboveground growth in late spring and storage in late summer) that were not observed in oak. We report a fast transfer of recent photosynthates to the mycorhizosphere and we conclude that the patterns of carbon allocation belowground are species specific and change seasonally according to the phenology of the species.

\section{Introduction}

Soil $\mathrm{CO}_{2}$ efflux is the major biospheric source of carbon from terrestrial ecosystems to the atmosphere and it accounts for a large fraction (40-70\%) of total ecosystem respiration (Janssens et al., 2001). It includes the respiration of microorganisms and soil meso- or macroorganisms involved in the mineralisation of soil organic matter ("heterotrophic respiration"), and the use of recently assimilated substrates that fuels root metabolism and rhizospheric microorganisms that

Published by Copernicus Publications on behalf of the European Geosciences Union. 
are either associated to roots (symbionts) or that feed on root exudates ("rhizospheric" respiration, Epron, 2009; Subke et al., 2006). The transfer of photosynthetic products belowground therefore fulfils energy requirements of metabolic processes occurring in the root and associated rhizosphere.

Up to recently, temporal variations of soil $\mathrm{CO}_{2}$ efflux were mostly ascribed to environmental drivers (e.g. Bahn et al., 2010; Epron et al., 1999; Raich et al., 2002), but there is now a growing amount of evidence that soil $\mathrm{CO}_{2}$ efflux is strongly linked to plant activities (Högberg and Read, 2006; Ryan and Law, 2005; Trumbore, 2006). Beyond the relationships between ecosystem productivity and soil $\mathrm{CO}_{2}$ efflux at a regional scale (Janssens et al., 2001), temporal variations in soil $\mathrm{CO}_{2}$ efflux were recently ascribed to short-term changes in microclimatic conditions (e.g. photon flux density, vapour pressure deficit, air temperature) that affect canopy photosynthesis (Craine et al., 1999; Gaumont-Guay et al., 2008; Tang et al., 2005). Not only the total flux of soil $\mathrm{CO}_{2}$ efflux but also its ${ }^{13} \mathrm{C}$ composition was correlated to short-term fluctuations in microclimate confirming a close coupling between photosynthesis and soil $\mathrm{CO}_{2}$ efflux (Bowling et al., 2008; Ekblad et al., 2005; Marron et al., 2009; Mortazavi et al., 2005).

Root and root-derived carbohydrates contribute to 50 $60 \%$ of soil $\mathrm{CO}_{2}$ efflux in forest ecosystems (Subke et al., 2006) highlighting the effect of photosynthesis on soil $\mathrm{CO}_{2}$ efflux. Soil $\mathrm{CO}_{2}$ efflux will therefore vary according to temporal change in canopy photosynthesis but the coupling will depend on both the velocity of carbon transfer belowground (Kuzyakov and Gavrichkova, 2010; Mencuccini and Hölttä, 2010; Plain et al., 2009) and on the partitioning of photosynthates among several pools and organs within the tree, i.e. on carbon allocation (Litton et al., 2007). The contribution of recent photosynthate to soil $\mathrm{CO}_{2}$ efflux further depends on the partitioning of carbon allocated belowground to growth, storage and respiration of both root and microorganisms feeding on root-derived carbohydrates (Ryan and Law, 2005). This will affect the residence time of carbon in the tree-soil system before it returns to the atmosphere.

Total annual belowground carbon allocation can be successfully derived from soil $\mathrm{CO}_{2}$ efflux and litterfall using a mass balance equation (Giardina and Ryan, 2002). It varies with stand age and resource availability (Litton et al., 2007). It increases with mean annual temperature at global scale (Litton and Giardina, 2008). However, there is still little information on the seasonal variations of belowground carbon allocation in forest ecosystems. The strength of the different carbon sinks is thought to change seasonally and among species (Körner, 2003). Differences in carbon allocation patterns in spring between diffuse porous and ring-porous species are well-known (Barbaroux and Bréda, 2002). The latter should start their radial stem growth prior leaf expansion to restore hydraulic conductivity after winter embolism of large vessels (Bréda and Granier, 1996). Similarly, evergreen and deciduous trees exhibit different seasonal patterns of the contribution of stored and recent carbon to respiration (Kuptz et al., 2011). Besides phenology, a direct control of allocation by environmental drivers cannot be excluded. Drought reduced the contribution of recent photosynthate to soil $\mathrm{CO}_{2}$ efflux and the transfer of carbon into the microbial biomass in young potted beech (Ruehr et al., 2009). Both soil water content and temperature affected carbon allocation to microbial biomass in Ericaceae species (Gorissen et al., 2004) and the velocity of carbon transfer in the trunk of oak and pine (Dannoura et al., 2011). In the latter study, we demonstrated that pulse labelling of field-grown trees with ${ }^{13} \mathrm{CO}_{2}$ and high frequency of measurement of ${ }^{13} \mathrm{C}$ in respiratory efflux during the chase period using laser-based infrared gas analysers is a powerful approach to study seasonal variations of carbon transfer (see also Bahn et al., 2009, on grassland).

The aim of this study was to assess the belowground transfer of recently assimilated carbon in two deciduous broadleaved species (beech and oak) and one coniferous evergreen species (maritime pine) at distinct phenological stages during the growing season. ${ }^{13} \mathrm{CO}_{2}$ recovery in soil $\mathrm{CO}_{2}$ efflux was recorded for 3 weeks by tuneable diode laser absorption spectrometers (TDLAS) after pulse labelling of 8-10 $\mathrm{m}$ tall trees and compared to ${ }^{13} \mathrm{C}$ recovery in both root and microbial biomass and their respective respiratory $\mathrm{CO}_{2}$. We hypothesised that (i) the transfer time would vary between broadleaved and coniferous species due to difference in anatomy that affect the velocity of carbon transport in the phloem (Dannoura et al., 2011) and growth rhythm (deciduous versus evergreen species), (ii) the amount of ${ }^{13} \mathrm{C}$ recovered in soil $\mathrm{CO}_{2}$ efflux would vary along the season reflecting changes in carbon allocation related to phenology, temperature and soil water content, and (iii) ${ }^{13} \mathrm{C}$ would be first recovered in the roots and later in the microbial biomass.

\section{Materials and methods}

\subsection{Study sites and experimental design}

The study was conducted on three temperate forest stands (Dannoura et al., 2011): a 20 yr-old natural beech regeneration on a luvisol (Fagus sylvatica L., $48^{\circ} 40^{\prime} \mathrm{N}, 7^{\circ} 04^{\prime} \mathrm{E}$, $300 \mathrm{~m}$ elevation), a $15 \mathrm{yr}$-old natural sessile oak regeneration on a gleyic luvisol (Quercus petraea Matt Liebl, $48^{\circ} 2^{\prime} \mathrm{N}$, $02^{\circ} 47^{\prime}$ E, 90 m elevation) and a 12 yr-old maritime pine plantation on a sandy podsol (Pinus pinaster Ait, $44^{\circ} 45^{\prime} \mathrm{N}$, $0^{\circ} 42^{\prime} \mathrm{W}, 60 \mathrm{~m}$ elevation). Tree density was $1.6,1.5$ and 0.25 trees per $\mathrm{m}^{2}$ for beech, oak and pine, respectively.

Labelling was done three to four times covering the whole leafy season for all species. Three trees were selected for each labelling date in all sites and two of them were labelled. Tree height ranged between 8 to $10 \mathrm{~m}$ in all stands (DBH are given in Table 1). A $0.5-0.6 \mathrm{~m}$ deep trench was dug around each tree at least 5 months before labelling to limit possible 
Table 1. Diameter at $1.3 \mathrm{~m}$ height $(\mathrm{DBH}, \mathrm{cm})$, cumulative photosynthetic photon flux density (PPFD, mol m $\mathrm{m}^{-2} \mathrm{~d}^{-1}$ ) over $24 \mathrm{~h}$ following the beginning of labelling, air temperature $\left(T_{\mathrm{A}},{ }^{\circ} \mathrm{C}\right)$ averaged over $24 \mathrm{~h}$ following the beginning of labelling, volumetric soil water content (SWC, $\left.\mathrm{m}^{3} \mathrm{~m}^{-3}\right)$ on the day of labelling. Soil $\mathrm{CO}_{2}$ efflux $\left(F_{\mathrm{S}}, \mathrm{mgC} \mathrm{m}^{-2} \mathrm{~h}^{-1}\right)$, root mass per unit area $\left(M_{\mathrm{R}}, \mathrm{gDM} \mathrm{m}^{-2}\right)$, specific root respiration $\left(R_{\mathrm{R}}, \mathrm{mgC} \mathrm{kg}_{\mathrm{DM}}^{-1} \mathrm{~h}^{-1}\right)$, microbial carbon per unit area $\left(\mathrm{C}_{\mathrm{M}}, \mathrm{gC} \mathrm{m}^{-2}\right)$ and microbial respiration $\left(R_{\mathrm{M}}, \mathrm{mgC} \mathrm{kg}_{\text {soil }}^{-1} \mathrm{~h}^{-1}\right)$ were averaged over the entire chase period (20 days). Time lag in ${ }^{13} \mathrm{C}$ recovery in soil $\mathrm{CO}_{2}$ efflux ( $L$, day), asymptotic value of cumulative label recovered in soil $\mathrm{CO}_{2}$ efflux $\left(\mathrm{CLR}_{\mathrm{FS}}(\infty)\right.$ in $\left.\mathrm{mg}^{13} \mathrm{C}\right)$ and half residence time $\left(t 1 / 2\right.$, day) were estimated by fitting cumulative label recovered in soil $\mathrm{CO}_{2}$ efflux to Eqs. (9-11).

\begin{tabular}{|c|c|c|c|c|c|c|c|c|c|c|c|c|}
\hline Date of labelling & $\mathrm{DBH}$ & PPFD & $T_{\mathrm{A}}$ & SWC & $F_{\mathrm{S}}$ & $M_{\mathrm{R}}$ & $R_{\mathrm{R}}$ & $\mathrm{C}_{\mathrm{M}}$ & $R_{\mathrm{M}}$ & $L$ & $\operatorname{CLR}_{\mathrm{FS}}(\infty)$ & $t 1 / 2$ \\
\hline \multicolumn{13}{|l|}{ Beech } \\
\hline 19 May 2009 & 5.0 & 48.1 & 16.4 & 0.37 & 206 & 205 & 65 & 39 & 4.5 & 1.13 & 426 & 6.63 \\
\hline 27 May 2009 & 7.3 & 40.1 & 13.1 & 0.36 & 105 & 297 & 93 & 33 & 4.4 & 0.92 & 371 & 9.13 \\
\hline 6 July 2009 & 7.8 & 43.8 & 17.5 & 0.32 & 214 & 343 & 104 & 44 & 4.3 & 0.67 & 2534 & 6.21 \\
\hline 10 July 2009 & 7.3 & 46.2 & 14.8 & 0.31 & 231 & 282 & 122 & 48 & 5.4 & 0.50 & 2128 & 4.92 \\
\hline 17 August 2009 & 4.9 & 43.6 & 21.2 & 0.39 & 79 & 186 & 67 & 35 & 2.7 & 1.33 & 93 & 4.83 \\
\hline 19 August 2009 & 6.6 & 50.7 & 23.7 & 0.36 & 99 & 246 & 80 & 41 & 3.0 & 0.67 & 599 & 5.96 \\
\hline 23 August 2009 & 6.2 & 51.7 & 18.3 & 0.23 & 122 & 192 & 72 & 32 & 1.9 & 1.33 & 694 & 13.13 \\
\hline 24 August 2009 & 6.0 & 40.2 & 23.4 & 0.13 & 75 & 292 & 82 & 41 & 2.6 & 0.75 & 468 & 4.17 \\
\hline \multicolumn{13}{|l|}{ Oak } \\
\hline 19 May 2009 & 8.9 & 40.3 & 14.6 & 0.30 & 227 & 103 & 79 & 58 & 6.2 & 0.63 & 828 & 6.25 \\
\hline 27 May 2009 & 8.1 & 26.9 & 15.2 & 0.29 & 133 & 99 & 66 & 61 & 6.6 & 0.79 & 914 & 6.13 \\
\hline 30 June 2009 & 9.6 & 56.5 & 24.3 & 0.24 & 296 & 95 & 153 & 57 & 8.1 & 0.58 & 1064 & 5.96 \\
\hline 8 July 2009 & 8.6 & 21.4 & 14.3 & 0.23 & 294 & 97 & 95 & 68 & 4.5 & 0.75 & 867 & 6.13 \\
\hline 31 August 2009 & 8.9 & 14.8 & 22.5 & 0.20 & 163 & 95 & 56 & 62 & 2.0 & 1.08 & 729 & 7.00 \\
\hline 9 September 2009 & 8.1 & 18.4 & 20.8 & 0.21 & 140 & 90 & 77 & 98 & 3.2 & 1.04 & 1362 & 7.67 \\
\hline \multicolumn{13}{|l|}{ Pine } \\
\hline 12 June 2009 & 12.0 & 63.6 & 21.1 & 0.10 & 177 & 39 & 449 & 13 & 2.3 & 1.75 & 1380 & 4.88 \\
\hline 17 June 2009 & 14.7 & 76.4 & 19.6 & 0.16 & 246 & 51 & 374 & 18 & 2.13 & 1.63 & 1152 & 6.04 \\
\hline 3 August 2009 & 15.0 & 50.3 & 19.8 & 0.08 & 174 & 57 & & 16 & & 2.46 & 960 & 7.54 \\
\hline 4 August 2009 & 11.3 & 62.8 & 23.4 & 0.09 & 169 & 53 & & 15 & & 1.96 & 1332 & 6.83 \\
\hline 27 October 2009 & 12.1 & 18.0 & 13.3 & 0.05 & 102 & & & 24 & & 2.71 & 948 & 6.21 \\
\hline 17 November 2009 & 14.1 & 26.9 & 16.6 & 0.12 & 64 & & & 32 & & 4.04 & 474 & 15.25 \\
\hline 18 February 2010 & 14.0 & 15.9 & 10.6 & 0.18 & 23 & & & 23 & & 4.17 & 96 & 11.00 \\
\hline 23 February 2010 & 13.8 & 78.1 & 11.6 & 0.17 & 37 & & & 31 & & 4.38 & 564 & 23.63 \\
\hline
\end{tabular}

confounding effects of root cutting on carbon allocation. The trench was lined with a polyethylene film and filled back. All roots and root exudates within this soil volume therefore originated from the isolated tree, and were contained in this trench volume. The areas delimited by the trench were about $3 \mathrm{~m}^{2}$ in the beech (2.9-3.8) and oak stands (2.2-5.7), and $6 \mathrm{~m}^{2}$ in the pine stand and were larger than the average areas per tree (inverse of tree density).

In early spring 2009 and at least three months prior to the labelling to allow enough time for ingrowth of mycorrhizal hyphae, root exclusion cores were installed in those trench plots that were selected for the labelling experiment. A root auger $(\varnothing 8 \mathrm{~cm}$; depth of corer $15 \mathrm{~cm})$ was used to extract intact soil cores to a depth of $15 \mathrm{~cm}$. Upon removal of the auger, the soil was gently pushed out with a crank and wrapped in a $30 \mu \mathrm{m}$ nylon mesh bag of similar dimensions
(BUISINE, Clermont de l'Oise, France) and then put back in the core hole. The $30 \mu \mathrm{m}$ mesh excludes root growth in the cores so that the main passage for labelled carbon into these root exclusion cores is by hyphae of mycorrhizal fungi. Of course, passive diffusion or motile bacteria mediated transfer of labelled carbon cannot be excluded. During the chase period, the root exclusion cores were retrieved and compared to normal cores collected freshly with the same auger.

In April 2009, rainfall exclusion roofs, made with polyethylene film and supported by a woody frame $(3 \times 3 \mathrm{~m})$, were installed $1.5 \mathrm{~m}$ above the forest floor on two beech trees to divert rainfall from the soil delimited by the trench. Predawn leaf water potential was measured once on 3 to 4 leaves per tree just prior labelling using a Scholandertype pressure chamber (PMS instrument, Corvallis, Oregon, USA). 
Photosynthetic photon flux density (PPFD; Delta T-BF2, Cambridge, UK for beech, home-made quantum sensor using a gallium arsenide photodiode for oak and DBE, Solems, Palaiseau, France for pine), air temperature $\left(T_{\mathrm{A}}\right.$; Vaisala HMP45, Helsinki, Finland) and soil temperature at $10 \mathrm{~cm}$ depth ( $T_{\mathrm{S}}$, home-made copper-constantan thermocouples) were recorded half-hourly at each site. Values were averaged for 24,48 or $72 \mathrm{~h}$ after labelling. Soil water content (SWC) in the vicinity of each labelled tree inside the area delimited by the trench was recorded half hourly at $30 \mathrm{~cm}$ depth for pine with TDR probes (CS616, Campbell Scientific, Logan, UT, USA) or at $10 \mathrm{~cm}$ depth for oak with an impedance probe (ML2x ThetaProbes, Delta-T Device, Cambridge, UK), or measured once a week at $15 \mathrm{~cm}$ depth for beech using TDR probes (Trase, SoilMoisture Equipment Corp., Santa Barbara, CA, USA).

\subsection{Crown labelling}

The whole crown of the tree was inserted into a 20 to $40 \mathrm{~m}^{3}$ chamber made of $200 \mu \mathrm{m}$ polyane film (celloflex 4TT; Prosyn polyane, Saint-Chamond, France) and held by two $12 \mathrm{~m}$ height stainless steel scaffoldings put up on both sides of the tree (Plain et al., 2009). Air temperature inside the crown labelling chamber was recorded, controlled and maintained at the outside air temperature. Evolution of $\left[{ }^{12} \mathrm{CO}_{2}\right]$ and $\left[{ }^{13} \mathrm{CO}_{2}\right]$ inside the chamber was monitored with a ${ }^{12} \mathrm{CO}_{2} /{ }^{13} \mathrm{CO}_{2}$ infrared gas analyser (S710, SICK/MAIHAK, Reute, Germany, accuracy of 5\%). A total amount of $50.4 \mathrm{~g}$ of pure ${ }^{13} \mathrm{CO}_{2}$ (99.299 atom \%, Eurisotop, Cambridge Isotope Laboratory Inc., Andover, MA, USA) was progressively injected for 1 to $5 \mathrm{~h}$ at a flow rate adjusted to maintain the ${ }^{13} \mathrm{CO}_{2}$ mixing ratio in the chamber between 300 and $400 \mu \mathrm{mol} \mathrm{mol}^{-1}$, except in November and February for pine where higher ${ }^{13} \mathrm{CO}_{2}$ mixing ratios $\left(800-1000 \mu \mathrm{mol} \mathrm{mol}^{-1}\right)$ were used to compensate a lower photosynthetic activity (see Dannoura et al., 2011; Plain et al., 2009 for more details). By only inserting the crown into the labelling chamber, we avoided contamination of the soil atmosphere by diffusion of ${ }^{13} \mathrm{CO}_{2}$ into the soil pores that would later have back-diffused into the atmosphere leading to an artefact in soil $\mathrm{CO}_{2}$ efflux isotopic composition (Subke et al., 2009).

\section{$2.3{ }^{13} \mathrm{C}$ in soil $\mathrm{CO}_{2}$ efflux}

The isotope composition of soil $\mathrm{CO}_{2}$ efflux $\left(\delta^{13} \mathrm{C}_{\mathrm{FS}}\right)$ was computed from $\left[{ }^{12} \mathrm{CO}_{2}\right]$ and $\left[{ }^{13} \mathrm{CO}_{2}\right]$ measured at the inlet and outlet of flow-through soil $\mathrm{CO}_{2}$ efflux chambers (Marron et al., 2009; Plain et al., 2009) by tuneable diode laser absorption spectroscopy with a trace gas analyzer (TGA 100A; Campbell Scientific, Logan, UT). Two or three collars were installed for each tree at $60 \mathrm{~cm}$ from the trunk. Air was pumped continuously through the chamber at a flow rate ranging from 18 to $72 \mathrm{dm}^{3} \mathrm{~h}^{-1}$. The chamber design ensured that differences in pressure between the inside and the out- side of the chamber remained below $10^{-2} \mathrm{~Pa}$. A manifold was used to switch between working standards and the chamber inlet and outlet lines. A mean mixing ratio was recorded over $20 \mathrm{~s}$ after a $30 \mathrm{~s}$ stabilisation. The isotope composition of each working standard that was $0.5 \%$ certified for $\mathrm{CO}_{2}$ mixing ratios (Air Products, Paris, France for beech, Air Liquide, Paris, France for oak and DEUSTE Steininger GmbH, Mühlhausen, Germany for pine) was measured by an isotope ratio mass spectrometer (IRMS, Delta S, ThermoFinnigan, Bremen, Germany). The ranges of available mixing ratios were respectively from 293.2 to $1281.2 \mu \mathrm{mol} \mathrm{mol}^{-1}$ for ${ }^{12} \mathrm{CO}_{2}$ and from 3.17 to $13.75 \mu \mathrm{mol} \mathrm{mol}{ }^{-1}$ for ${ }^{13} \mathrm{CO}_{2}$. The precision of the instrument at reproducing calibration tank values was $0.3 \mu \mathrm{mol} \mathrm{mol}^{-1}$ and $0.007 \mu \mathrm{mol} \mathrm{mol}^{-1}$ for ${ }^{12} \mathrm{CO}_{2}$ and ${ }^{13} \mathrm{CO}_{2}$ (Dannoura et al., 2011).

The isotopic composition of soil $\mathrm{CO}_{2}$ effluxes $\left(\delta \mathrm{C}_{\mathrm{FS}}, \%\right.$ o $)$ was calculated as:

$\delta^{13} \mathrm{C}_{\mathrm{F}}=\frac{\frac{\left[{ }^{13} \mathrm{CO}_{2}\right]_{\text {out }}-\left[{ }^{13} \mathrm{CO}_{2}\right]_{\text {in }}}{\left[{ }^{12} \mathrm{CO}_{2}\right]_{\text {out }}-\left[{ }^{12} \mathrm{CO}_{2}\right]_{\text {in }}}}{R_{\text {VPDB }}}-1$

where $R_{\mathrm{VPDB}}$ is the isotopic ratio of Vienna Pee Dee Belemnite (Coplen et al., 2002).

Total $\mathrm{CO}_{2}$ mixing ratio $\left(\left[\mathrm{CO}_{2}\right], \mu \mathrm{mol} \mathrm{mol}{ }^{-1}\right)$ was calculated from the mixing ratios of individual isotopologues by:

$\left[\mathrm{CO}_{2}\right]=\frac{\left[{ }^{12} \mathrm{CO}_{2}\right]_{+}\left[{ }^{13} \mathrm{CO}_{2}\right]}{\left(1-f_{\text {other }}\right)}$

where $f_{\text {other }}$ is the fraction of $\mathrm{CO}_{2}$ containing all isotopologues other than ${ }^{12} \mathrm{C}^{16} \mathrm{O}^{16} \mathrm{O}$ and ${ }^{13} \mathrm{C}^{16} \mathrm{O}^{16} \mathrm{O}$, and assumed to be 0.00474 (Griffis et al., 2004).

\section{$2.4{ }^{13} \mathrm{C}$ in respiratory $\mathrm{CO}_{2}$ of roots and soil microorganisms}

Two soil cores (20 cm depth) were collected 1, 3, 6, 9 and 15 days after labelling and sliced into 3 parts $(0-5,5-10$ and $10-20 \mathrm{~cm})$. The soil was immediately sieved through a $2-$ $\mathrm{mm}$ mesh and living fine root fragments (diameter $<2 \mathrm{~mm}$ ) were picked up and rinsed. Coarse root fragments were discarded. For each core, the fine roots collected at all depths were pooled together. Oak and pine roots of the two cores were further pooled to obtain a sufficient sample size while beech roots were kept separately for each core. Each root sample was then enclosed in a $125 \mathrm{ml}$ glass flask. A pump was used to circulate gas from the flask to an IRGA (EGM1, PPSystems, Hitchin, UK, LI840, Licor, Lincoln, USA or S710, SICK/MAIHAK, Reute, Germany). The $\mathrm{CO}_{2}$ initially inside the flask was removed using a soda lime trap. After $10 \mathrm{~min}$, the soda lime trap was by-passed and the increase in $\mathrm{CO}_{2}$ mixing ratio in the flask was recorded until reaching values above $400 \mathrm{ppmv}$. Air was then sampled in a $10 \mathrm{ml}$ Exetainer glass-vial (Labco limited, High Wycombe, UK) or 25-ml glass flask for IRMS analyses. Root-free soil subsamples (approx $150 \mathrm{~g}$ ) from $0-5$ and $5-10 \mathrm{~cm}$ depth were incubated similarly in $250 \mathrm{ml}$ flask. Soil from the two cores 
was pooled for oak. The isotopic composition $(\delta)$ of $\mathrm{CO}_{2}$ in sampled air was measured within a week IRMS (Delta-S, Finnigan-Mat, Thermoquest Corp., San Jose, CA, USA, for beech and pine samples or VG Optima, Fison, Villeurbanne, France, for oak samples) coupled to a gas purification device (Gas-Bench II, ThermoFinnigan, Bremen, Germany). Incubations were done on all beech and oak trees but for pine only those labelled in June. Temperature during incubation was $19-22^{\circ} \mathrm{C}$ for beech and oak, and $22-24^{\circ} \mathrm{C}$ for pine.

\section{$2.5{ }^{13} \mathrm{C}$ in root and microbial carbon}

After incubation, roots were immediately plunged in liquid nitrogen, transferred into a $-80^{\circ} \mathrm{C}$ freezer and finally freezedried. Freeze-dried root samples were ground, weighed and analysed for carbon isotope composition and total carbon using an elemental analyser (NA 1500 NCS, Carlo Erba, Milan, Italy) coupled to IRMS.

After incubation, soil subsamples were stored at $4{ }^{\circ} \mathrm{C}$ for less than 4 days before processing for microbial carbon. The $\delta^{13} \mathrm{C}$ of soil microbial carbon was determined from $\delta^{13} \mathrm{C}$ of soluble carbon extracted from two $40 \mathrm{~g}$ of soil subsamples. One subsample was fumigated for $24 \mathrm{~h}$ with chloroform vapour, while the other was not fumigated (Vance et al., 1987). Extraction was performed using $0.05 \mathrm{M}^{\circ} \mathrm{K}_{2} \mathrm{SO}_{4}$ for one hour under vigorous shaking. The extracts were filtered, analysed for carbon content using a total organic carbon analyser (Shimadzu TOC-VCSH, Tokyo, Japan), either freeze-dried or oven-dried at $60^{\circ} \mathrm{C}$ (we observed no difference between the two methods) and then analysed for carbon isotope composition IRMS. Microbial carbon was also extracted from the deepest part of the soil cores in beech and pine $(10-20 \mathrm{~cm})$.

The isotope composition of soil microbial carbon $\left(\delta^{13} \mathrm{C}_{\mathrm{M}}\right)$ was calculated as:

$\delta^{13} \mathrm{C}_{\mathrm{M}}=\frac{\delta^{13} \mathrm{C}_{\text {fum }} \cdot \mathrm{C}_{\text {fum }}-\delta^{13} \mathrm{C}_{\text {nonfum }} \cdot \mathrm{C}_{\text {nonfum }}}{\mathrm{C}_{\text {fum }}-\mathrm{C}_{\text {nonfum }}}$

where $\mathrm{C}_{\text {fum }}$ and $\mathrm{C}_{\text {nonfum }}\left(\mathrm{mgC} \mathrm{kg}_{\text {soil }}^{-1}\right)$ refer to fumigated and non fumigated extracts.

Soil microbial carbon was computed as:

$\mathrm{C}_{\mathrm{M}}=\frac{\left(\mathrm{C}_{\text {fum }}-\mathrm{C}_{\mathrm{unfum}}\right)}{0.45}$

where 0.45 is a correction factor used to account for the nonextractable fraction of microbial carbon (Vance et al., 1987). However, the fumigation efficiency in the sandy soils of the pine stands can be higher since the microbe protection is probably low in these unstructured soils (Achat et al., 2010).

The isotope composition of microbial carbon was also estimated in the two root exclusion cores that were collected 3 and 6 days after labelling in beech and oak, and 6 and 9 days after labelling in pine, and sliced into two parts $(0-5$ and $5-10 \mathrm{~cm}$ ).
Gravimetric soil water content was determined by comparing the mass of approx. $40 \mathrm{~g}$ of soil before and after drying at $105^{\circ} \mathrm{C}$.

\subsection{Calculations}

The relative abundance of ${ }^{13} \mathrm{C}$ in any efflux or compartment (Ab) was calculated from the isotope composition as:

$\mathrm{Ab}=\frac{{ }^{13} \mathrm{C}}{{ }^{12} \mathrm{C}+{ }^{13} \mathrm{C}}=\frac{\left(\frac{\delta^{13} \mathrm{C}}{1000}+1\right) \cdot R_{\mathrm{VPDB}}}{\left[\left(\frac{\delta^{13} \mathrm{C}}{1000}+1\right) \cdot R_{\mathrm{VPDB}}\right]+1}$

$\mathrm{Ab}$ was corrected for the background ${ }^{13} \mathrm{C}$ content measured on unlabelled trees or on the same tree one day before labelling $\left(\mathrm{Ab}_{\mathrm{UN}}\right)$, and multiplied by $X, X$ being either the total carbon content in a compartment (root, $\mathrm{C}_{\mathrm{R}}$, or microbial carbon, $\mathrm{C}_{\mathrm{M}}$ ) or the $\mathrm{CO}_{2}$ flux to estimate the excess amount of ${ }^{13} \mathrm{C}\left(\right.$ Excess $\left.{ }^{13} \mathrm{C}\right)$ in that efflux or compartment:

Excess ${ }^{13} \mathrm{C}=\left(\mathrm{Ab}-\mathrm{Ab} \mathrm{bN}_{\mathrm{N}}\right) \cdot X$

Root and microbial respiration $\left(R_{\mathrm{R}}\right.$ and $\left.R_{\mathrm{M}}, \mathrm{mgC} \mathrm{kg}^{-1} \mathrm{~h}^{-1}\right)$ were calculated from the linear slope of the increase in $\mathrm{CO}_{2}$ mixing ratio in the incubation flasks $\left(d\left[\mathrm{CO}_{2}\right] / d t\right.$, $\mathrm{mol} \mathrm{mol}^{-1} \mathrm{~h}^{-1}$ ):

$R=\frac{d\left[\mathrm{CO}_{2}\right]}{d t} \cdot \frac{P \cdot V \cdot(13 \cdot \mathrm{Ab}+12 \cdot(1-\mathrm{Ab})) \cdot 10^{-3}}{8.314 \cdot T \cdot M}$

where $P$ is the atmospheric pressure $(\mathrm{Pa}), V$ is the total volume including flask, tubes and IRGA cells $\left(\mathrm{m}^{3}\right), M$ is the dry mass of the root or of the soil $(\mathrm{kg}), T$ is the temperature $(\mathrm{K})$, and $8.314 \mathrm{~J} \mathrm{~mol}^{-1} \mathrm{~K}^{-1}$ is the ideal gas constant.

Soil $\mathrm{CO}_{2}$ effluxes $\left(F_{\mathrm{S}}, \mathrm{mgC} \mathrm{m}^{-2} \mathrm{~h}^{-1}\right)$ were calculated as:

$F_{\mathrm{S}}=\frac{\left(\left[\mathrm{CO}_{2}\right]_{\text {out }}-\left[\mathrm{CO}_{2}\right]_{\text {in }}\right) \cdot P \cdot F \cdot(13 \cdot \mathrm{Ab}+12 \cdot(1-\mathrm{Ab})) \cdot 10^{-3}}{8.314 \cdot T \cdot S}$

where $F$ is the air flow through the chamber $\left(\mathrm{m}^{3} \mathrm{~h}^{-1}\right)$ and $S$ is the surface of soil chamber $\left(\mathrm{m}^{2}\right)$.

The cumulative label recovered in soil $\mathrm{CO}_{2}$ efflux $\left(\mathrm{CLR}_{\mathrm{FS}}\right)$ was calculated by summing daily averages of ${ }^{13} \mathrm{C}$ in excess in the soil $\mathrm{CO}_{2}$ efflux.

$\operatorname{CLR}_{\mathrm{FS}}(d)=\sum_{0}^{d} \overline{\left(F_{\mathrm{S}} \cdot\left(\mathrm{Ab}-\mathrm{Ab}_{\mathrm{UN}}\right)\right)} \cdot 24$

The kinetics of the label recovered in soil $\mathrm{CO}_{2}$ efflux were described using a four-pool model similar to those describing the supply of carbon for leaf growth (Lattanzi et al., 2005) or for root respiration (Lehmeier et al., 2008). The model was fitted on the observed $\mathrm{CLR}_{\mathrm{FS}}$ values (Fig. 1). A quantity of the label that will be respired belowground $(Q)$ leaves the crown pool $(\mathrm{C})$ at a rate following a first-order kinetics and arrives after a time lag $(L)$ into an active belowground pool (B1) where it can be transferred and back transferred to an inactive pool (B2) at rates following also a first-order kinetics. 


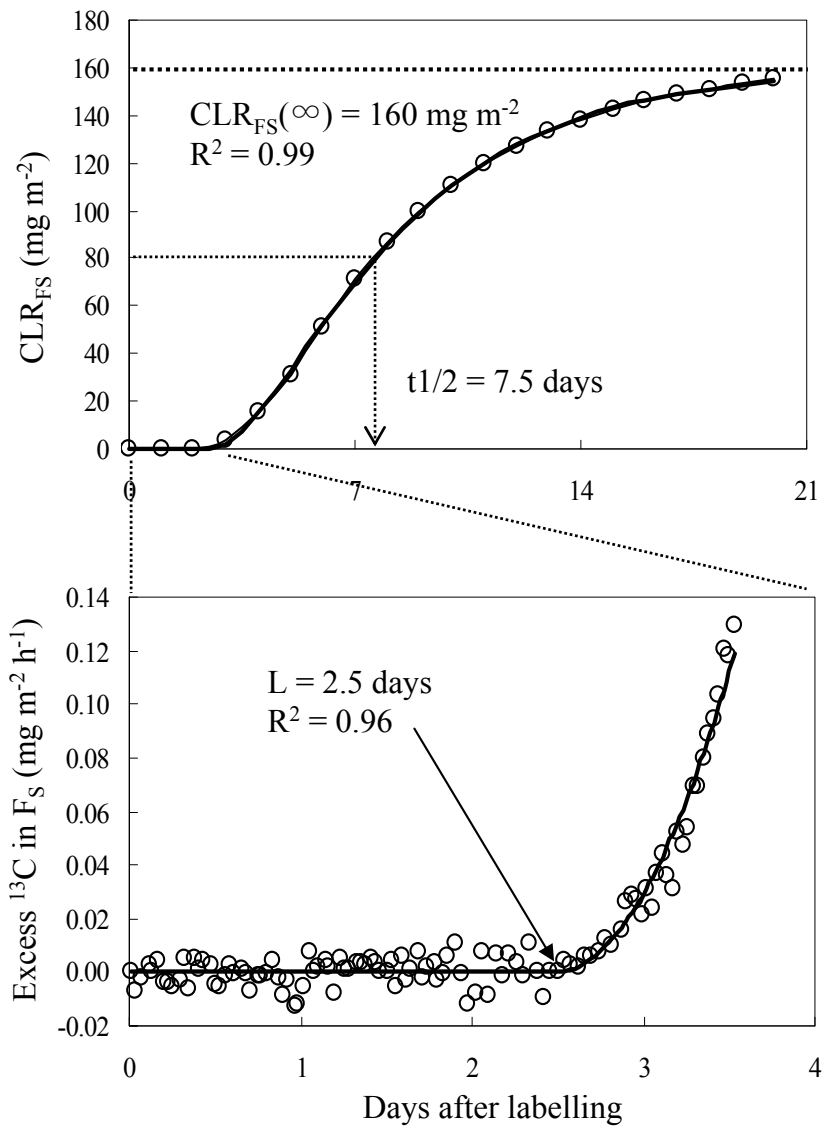

Fig. 1. Kinetics of cumulative excess ${ }^{13} \mathrm{C}$ in soil $\mathrm{CO}_{2}$ efflux $\left(\mathrm{CLR}_{\mathrm{FS}}\right.$, top panel) and kinetics of excess ${ }^{13} \mathrm{C}$ in soil $\mathrm{CO}_{2}$ efflux (Excess ${ }^{13} \mathrm{C}$ in $F_{\mathrm{S}}$ ). Open circles are measured data and the curves represent the best fits of Eqs. (9) and (11), respectively. The example shown is for pine labelled on 3 August 2009. Asymptotic value of $\operatorname{CLR}_{\mathrm{FS}}\left(\mathrm{CLR}_{\mathrm{FS}}(\infty)\right)$, half residence time of soil respired ${ }^{13} \mathrm{C}$ in the whole plant-soil system $(t 1 / 2)$ and time lag $(L)$ between the start of the labelling and the first appearance of ${ }^{13} \mathrm{C}$ in soil $\mathrm{CO}_{2}$ efflux are depicted on the graphs. In this example, the best-fitted rate constants are $k_{\mathrm{CB} 1}=0.022, k_{\mathrm{B} 1 \mathrm{~B} 2}=0.001, k_{\mathrm{B} 2 \mathrm{~B} 1}=0.130$ and $k_{\mathrm{B} 1 \mathrm{~A}}=0.022$.

Finally, the label leaves the substrate pool in a similar way and accumulates in the atmosphere (A). The rates of change in the different pools are:

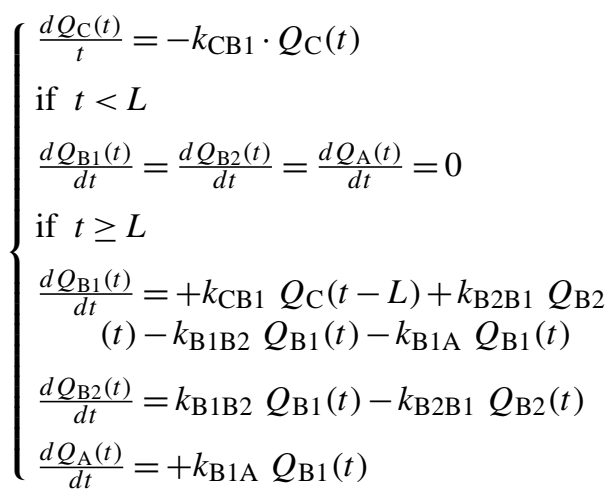

where $k_{\mathrm{CB} 1}, k_{\mathrm{B} 1 \mathrm{~B} 2}, k_{\mathrm{B} 2 \mathrm{~B} 1}$ and $k_{\mathrm{B} 1 \mathrm{~A}}$ are the rate constant of transfer between the crown to the B1 pool), between B1 and $\mathrm{B} 2$ pools (transfer and back transfer), and between $\mathrm{B} 1$ and the atmosphere (respiration).

The cumulative label recovered in soil $\mathrm{CO}_{2}$ efflux at any time $t$ is therefore:

$\operatorname{CLR}_{\mathrm{FS}}(t)=\int_{0}^{t} \frac{d Q_{\mathrm{A}}(t)}{d t}$

and the asymptotic value, $\operatorname{CLR}_{\mathrm{FS}}(\infty)$ is equal to $Q_{\mathrm{C}}(0)$. $\operatorname{CLR}_{\mathrm{FS}}(\infty)$ multiplied by the trenched surface represents the amount of carbon allocated to belowground respiration.

The $\mathrm{B} 1$ pool is a metabolically active pool that contributes to soil $\mathrm{CO}_{2}$ efflux while the $\mathrm{B} 2$ pool is metabolically inactive, and does not contribute to soil $\mathrm{CO}_{2}$ efflux. We also unsuccessfully tested a two-metabolically-active-pool model that would have represented roots and microorganisms. We are aware that our model is oversimplified and that it does not describe the complexity of the fate of carbon belowground. We consider this model as an empirical one acknowledging that the B1 and B2 compartments are virtual pools, and that calculating half residence time of label within each pool from the adjusted rate constants would have been misleading. We therefore used the model for estimating the seasonal variation in the amount of carbon allocated to soil $\mathrm{CO}_{2}$ efflux and we calculated the half residence time of soil respired ${ }^{13} \mathrm{C}$ into the whole plant-soil system $(t 1 / 2)$ as the time needed to reach $50 \%$ of $\mathrm{CLR}_{\mathrm{FS}}(\infty)$.

The time lag was not estimated from Eq. (9) but determined by fitting a quadratic function to the relationships between Excess ${ }^{13} \mathrm{C}$ in $F_{\mathrm{S}}$ and the time after labelling (Fig. 1) using non linear least-squares regression (PROC NLIN of SAS software, Marquardt-Levenberg method, SAS Institute Inc., Cary, NC, USA):

$$
\left\{\begin{array}{l}
\text { Excess }{ }^{13} \mathrm{C}=0 \text { if } t<L \\
\text { Excess }{ }^{13} \mathrm{C}=a(t-L)+b(t-L)^{2} \quad \text { if } t \geq L
\end{array}\right.
$$

The model predicted satisfactorily CLR $_{\mathrm{FS}}$ values at 7,14 and 20 days after labelling across species and seasons $\left(R^{2}=\right.$ $0.99, p<0.001$ ).

\subsection{Statistical analyses}

Data were analysed separately for each species using SAS software (SAS Institute Inc., Cary, NC, USA). Two-way ANOVA (tree and sampling date, nested within tree) were used for Excess ${ }^{13} \mathrm{C}$ in $F_{\mathrm{S}}, \mathrm{C}_{\mathrm{R}}$ and $R_{\mathrm{R}}$ and three-way ANOVA (tree, depth and sampling date nested within tree and depth, including interaction between tree and depth when the two cores were not pooled) were used for ${ }^{13} \mathrm{C}$ in excess in $\mathrm{C}_{\mathrm{M}}$ and $R_{\mathrm{M}}$. A four-way ANOVA was used to compare ${ }^{13} \mathrm{C}$ in excess in $\mathrm{C}_{\mathrm{M}}$ of normal cores and root exclusion cores (tree, depth, core type nested within tree and depth and sampling date nested within tree, depth and core type, including 
interactions between tree and depth when the two cores were not pooled). The residual errors of each model are shown as vertical bars in the figures. Linear correlations between the different parameters and environmental variables were tested with a two-tailed test for significance.

\section{Results}

\subsection{Excess ${ }^{13} \mathrm{C}$ in soil $\mathrm{CO}_{2}$ efflux}

Soil $\mathrm{CO}_{2}$ efflux $\left(F_{\mathrm{S}}\right)$ varied within a similar range in the three species according to seasons, with highest values in July for beech and oak and lowest values in February for pine (Table 1). A significant Excess ${ }^{13} \mathrm{C}$ in $F_{\mathrm{S}}$ was rapidly observed in beech and oak (Fig. 2) after a time lag ( $L$, Table 1) of less than 0.5 to 1.5 days. In oak, $L$ was negatively correlated to cumulative PPFD on the day of labelling $(R=-0.86$, $p<0.05$ ). Low cumulated PPFD were observed in September. $L$ was higher in pine than in the two broadleaved species during the growing season, including October labelling (1.6 to 2.5 days) and increased markedly in November and February, up to 4.4 days, and this increase was clearly related to the drop in temperature. In pine, $L$ was indeed negatively correlated to both air and soil temperature, with the highest correlation between $L$ and soil temperature averaged for 4 days since the start of the labelling $(R=-0.84, p<0.01)$.

In pine, the lowest $\operatorname{CLR}_{\mathrm{FS}}(\infty)$ values were observed for trees labelled in November and February, reflecting lower $F_{\mathrm{S}}$ values in these seasons (Table 1). $\operatorname{CLR}_{\mathrm{FS}}(\infty)$ was indeed positively related to both air and soil temperature, with the highest $R$ between $\operatorname{CLR}_{\mathrm{FS}}(\infty)$ and air temperature averaged for $24 \mathrm{~h}$ since the start of the labelling $(R=0.84, p<0.01)$. The marked influence of temperature on the shape of the time courses of Excess ${ }^{13} \mathrm{C}$ in soil $\mathrm{CO}_{2}$ efflux (Fig. 2) may explain the negative correlation between $\operatorname{CLR}_{\mathrm{FS}}(\infty)$ and $L$ in this species $(R=-0.92, p<0.01)$, which was not observed for the two broadleaved species. In beech and oak, $\operatorname{CLR}_{\mathrm{FS}}(\infty)$ was not related to any of the measured environmental factors. Despite the lack of relationships with climatic factors, there were clear seasonal differences in $\operatorname{CLR}_{\mathrm{FS}}(\infty)$ in beech with the higher $\operatorname{CLR}_{\mathrm{FS}}(\infty)$ observed in July (Table 1 ). Despite lower soil water content under rainfall exclusion roofs, this had no marked influence on $\operatorname{CLR}_{\mathrm{FS}}(\infty)$ in beech.

Half residence time of soil respired ${ }^{13} \mathrm{C}$ in the tree-soil system averaged 6.9 and 6.5 days in beech and oak respectively with no clear seasonal trend. It increased markedly in pine in November and February compared to June, August and October (Table 1), with the highest correlation between $t 1 / 2$ and air temperature averaged for $72 \mathrm{~h}$ since the start of the labelling $(R=-0.77, p<0.05)$. In oak and in pine, $t 1 / 2$ and $L$ are correlated $(R=0.87, p<0.05$ and $R=0.84, p<0.01$, respectively) but not in beech.
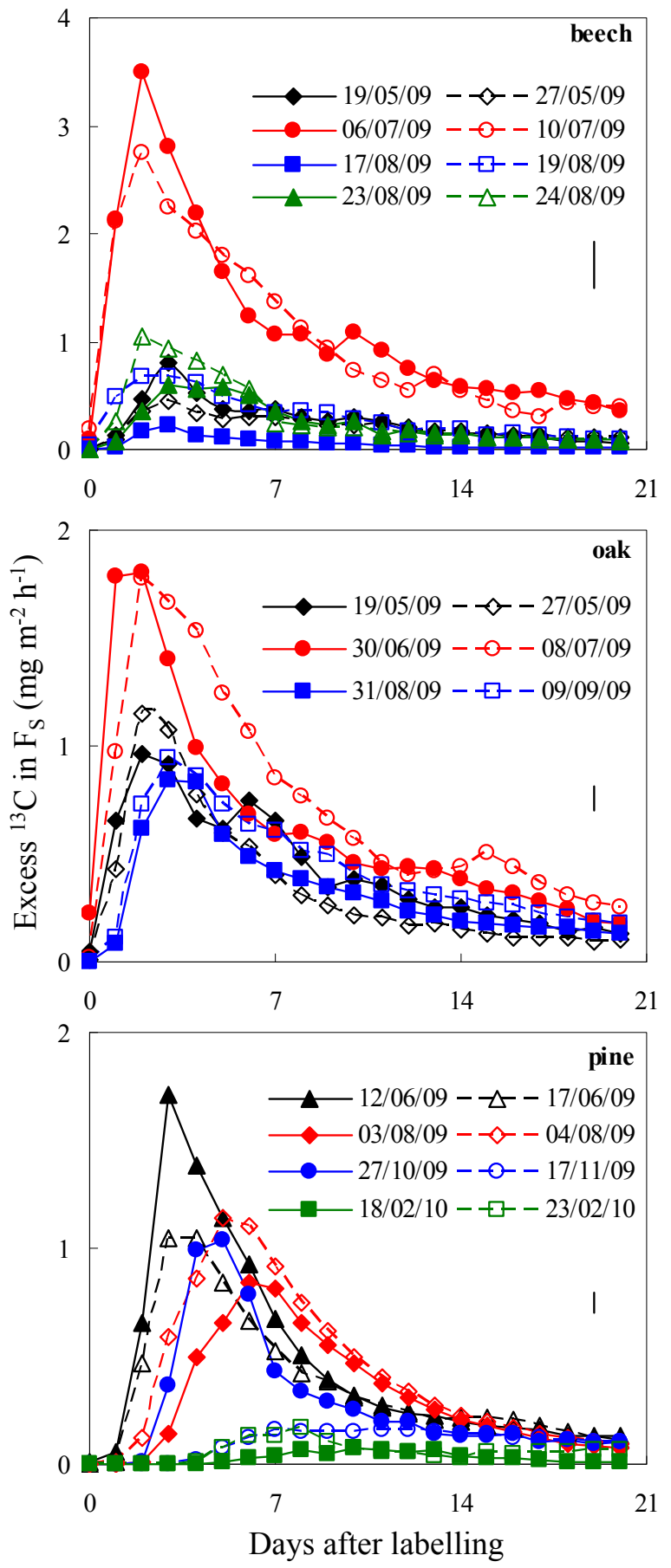

Fig. 2. Time courses of $24 \mathrm{~h}$ average of Excess ${ }^{13} \mathrm{C}$ in soil $\mathrm{CO}_{2}$ efflux $\left(F_{\mathrm{S}}\right)$ after whole crown pulse labelling of beeches (top), oaks (middle) and pines (bottom). Each tree is identified by its date of labelling. There are significant differences between trees $\left(F_{7,126}=41.0, F_{5,63}=63.9\right.$ and $F_{7,126}=114.2$ for beech, oak and pine respectively, $p<0.001)$ and between sampling dates $\left(F_{160,126}=2.75, F_{120,63}=14.3\right.$ and $F_{160,126}=15.8$ respectively, $p<0.001)$. The verticals bars represent the root mean error. 


\subsection{Excess ${ }^{13} \mathrm{C}$ in root and microbial respiration and root and microbial carbon}

Fine root biomass $(0-20 \mathrm{~cm}$ depth) was higher in beech $\left(255 \mathrm{gDM} \mathrm{m}^{-2}\right.$, values for each tree are in Table 1 , with $\mathrm{DM}$ for dry matter) than in oak $\left(96 \mathrm{gDM} \mathrm{m}^{-2}\right)$ and pine $\left(50 \mathrm{gDM} \mathrm{m}^{-2}\right)$, while specific root respiration was similar for beech and oak $\left(87 \mathrm{mgC} \mathrm{kg}^{-1} \mathrm{DMh}^{-1}\right)$ and much higher in pine $\left(411 \mathrm{mgC} \mathrm{kg}^{-1} \mathrm{DM} \mathrm{h}^{-1}\right.$, measured only in June 2009). Microbial carbon (0-10 cm depth) was higher in oak $\left(68 \mathrm{gC} \mathrm{m}^{-2}\right)$ than in beech $\left(39 \mathrm{gC} \mathrm{m}^{-2}\right)$ and pine $\left(22 \mathrm{gC} \mathrm{m}^{-2}\right)$. Microbial respiration was higher in oak (5.1 mgC kg soil $\mathrm{h}^{-1}$ on average) than in beech (3.6 mgC kg $\mathrm{moil}^{-1} \mathrm{~h}^{-1}$ ), with lower values in August especially for beech trees under rainfall exclusion roofs, and lower in pine (2.2 $\mathrm{mgC} \mathrm{kg}_{\text {soil }}^{-1} \mathrm{~h}^{-1}$, measured only in June 2009).

An excess amount of ${ }^{13} \mathrm{C}$ was already found one day after labelling in the root and microbial compartments (both carbon and respiration) in oak and beech. It occurred later in pine, i.e. three days after labelling during the growth season (June to October) and six days after labelling in November and February. Excess ${ }^{13} \mathrm{C}$ in the microbial compartment was higher in the top soil $(0-5 \mathrm{~cm})$ than at deeper soil depths for all species.

The patterns of Excess ${ }^{13} \mathrm{C}$ in microbial (Fig. 3) and root (Fig. 4) respiration and in microbial (Fig. 5) and root biomass (Fig. 6) were on the whole consistent with TDLAS data (Fig. 2). The mean value of Excess ${ }^{13} \mathrm{C}$ in $F_{\mathrm{S}}$ calculated over the chase period was well related with mean Excess ${ }^{13} \mathrm{C}$ in $R_{\mathrm{R}}$ in beech $(R=0.86, p<0.01)$, better than with Excess ${ }^{13} \mathrm{C}$ in $R_{\mathrm{M}}(R=0.77, p<0.05)$. A similar correlation was observed between Excess ${ }^{13} \mathrm{C}$ in $F_{\mathrm{S}}$ and Excess ${ }^{13} \mathrm{C}$ in $\mathrm{C}_{\mathrm{R}}(R=0.91, p<0.01)$ while no correlation was observed between Excess ${ }^{13} \mathrm{C}$ in $F_{\mathrm{S}}$ and Excess ${ }^{13} \mathrm{C}$ in $\mathrm{C}_{\mathrm{M}}$. In oak, Excess ${ }^{13} \mathrm{C}$ in $F_{\mathrm{S}}$ was only related to Excess ${ }^{13} \mathrm{C}$ in $R_{\mathrm{R}}$ $(R=0.85, p<0.05)$ while no correlation was observed between Excess ${ }^{13} \mathrm{C}$ in $F_{\mathrm{S}}$ and Excess ${ }^{13} \mathrm{C}$ in $R_{\mathrm{M}}, \mathrm{C}_{\mathrm{M}}$ or $\mathrm{C}_{\mathrm{R}}$. In pine, we found a weak correlation between Excess ${ }^{13} \mathrm{C}$ in $F_{\mathrm{S}}$ and Excess ${ }^{13} \mathrm{C}$ in $\mathrm{C}_{\mathrm{R}}(R=0.72, p<0.001)$.

Excess ${ }^{13} \mathrm{C}$ in $\mathrm{C}_{\mathrm{M}}$ and $R_{\mathrm{M}}$ was significantly lower in root exclusion cores compared to normal cores for beech, especially in July while CLR $\mathrm{FS}_{\mathrm{F}}(\infty)$ is maximal (Fig. 7). A similar but not significant difference between normal and root exclusion cores was observed for oak and pine.

\section{Discussion}

\subsection{Transfer time of carbon belowground}

Time lags estimated for beech and oak ranged from 0.5 to $1.3 \mathrm{~d}$ and Excess ${ }^{13} \mathrm{C}$ peaked 2 to 3 days after labelling, a value similar to those observed on $3 \mathrm{~m}$ tall poplars (Horwath et al., 1994; Mikan et al., 2000). The ${ }^{13} \mathrm{C}$ peak was observed after one day in $0.5 \mathrm{~m}$ tall beech seedlings (Ruehr et al., 2009) and after $0.5 \mathrm{~d}$ in silver birch seedlings (Pumpanen et al., 2009). Considering the path length from tree leaves to the soil in our experiment, the transfer times we report are shorter. This might be due to a better time resolution of measurements based on tuneable diode laser absorption spectrometry compared to those based on off-site isotope ratio mass spectrometry.

No other labelling experiments on tall trees were reported so far in natural conditions in the field. The transfer time of photosynthates to ecosystem respiration has been indirectly estimated by tracing fluctuation in natural abundance of ${ }^{13} \mathrm{C}$ related to climate-induced variations in discrimination during photosynthesis. Time lags of three to five days observed on 8-9 m tall Douglas fir (Bowling et al., 2002; McDowell et al., 2004) and in a loblolly pine plantation and a mixed hardwood forest (Mortazavi et al., 2005), which is higher than those observed in this study during the active growing season (1.62.7 days for pine).

In contrast with beech and oak for which recovery of ${ }^{13} \mathrm{C}$ was observed in soil $\mathrm{CO}_{2}$ efflux after a time lag of less than 1 day on average during the growing season, the time lags for pine ranged between 1.6 to 2.7 days from June to October, and more than four days in the resting season (November and February). The tracer peaked after 4 to 6 days in the first period, a range that is in agreement with those reported for 2-m tall Scots pines (Högberg et al., 2008) and 4-m tall black spruce (Carbone et al., 2007), after considering the difference in tree size. Similar differences were reported after ${ }^{14} \mathrm{C}$ labelling of small potted seedlings in the laboratory between coniferous species (Norway spruce and Scots pine) and silver birch (Pumpanen et al., 2009). The markedly different transfer time of ${ }^{13} \mathrm{C}$ belowground between the two broadleaved species and the pine highlights differences in the velocity of photosynthate transport via the phloem sap between angiosperm and gymnosperm that were related to differences in phloem anatomy (Dannoura et al., 2011; Wingate et al., 2010). The doubling of time lag and peak time between summer and winter time, as well as the delayed peak time (more than 10 days in the resting season) were consistent with an effect of temperature on phloem loading, especially on retrieval after leaching (Peuke et al., 2006), on the viscosity of phloem sap (Hölttä et al., 2009) or on the carbohydrate sink strength (Wingate et al., 2010) that may affect the velocity of phloem sap (Dannoura et al., 2011).

The soil tortuosity and moisture might have influenced the transfer time of $\mathrm{CO}_{2}$ from roots to the soil surface (Mencuccini and Hölttä, 2010; Stoy et al., 2007). However, this putative effect would have led to an underestimation of the contrast found between broadleaved and coniferous species since the pine trees of our study were on a sandy soil with higher porosity than the soils of the two broadleaved trees. In addition, the close coupling between soil surface efflux and incubation of either root or root-free soil indicates that time lags related to transport in the soil air space are negligible. 


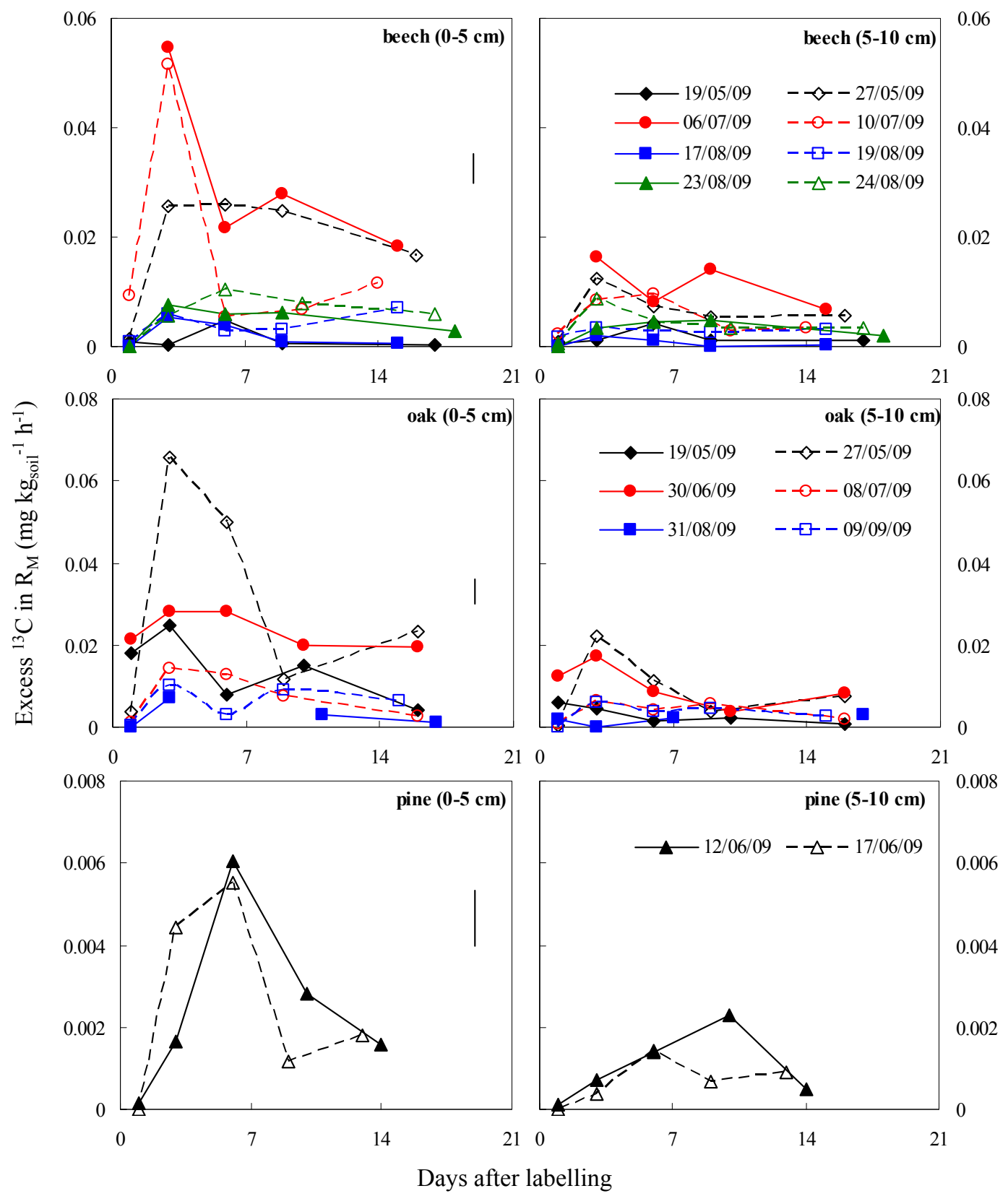

Fig. 3. Time courses of Excess ${ }^{13} \mathrm{C}$ in microbial respiration $\left(R_{\mathrm{M}}\right)$ after whole crown pulse labelling of beeches (top), oaks (middle) and pines (bottom) at $0-5 \mathrm{~cm}$ depth (left) and 5-10 cm depth (right). Each tree is identified by its date of labelling. There are significant differences between trees for beech $\left(F_{7,78}=23.1, p<0.001\right)$ and oak $\left(F_{5,23}=13.3, p<0.001\right)$, between depths $\left(F_{1,78}=44.9, F_{1,23}=31.7\right.$ and $F_{1,20}=15.8$ for beech, oak and pine respectively, $\left.p<0.001\right)$ and between sampling dates $\left(F_{64,78}=4.6, F_{23,23}=3.5\right.$ and $F_{16,20}=3.2$ for beech, oak and pine respectively, $p<0.001)$. The verticals bars represent the root mean error. Data are presented on two different panels according to depth but depth was included in the ANOVA.

The rainfall exclusion experiment conducted on two beech trees in August did not reveal any change in transfer time in contrast to what was observed on potted beech seedlings (Ruehr et al., 2009). The authors did not measure leaf water potential but both stomatal conductance and net photosynthesis of sapling leaves were markedly decreased in their exper- iment. Despite marked differences in soil water content $(0-$ $15 \mathrm{~cm}$ depth), there was however no difference in predawn leaf water potential $(-0.4 \mathrm{MPa})$ in our study indicating that we did not impose any substantial drought that would have affected the rate of phloem transport (Hölttä et al., 2009). 

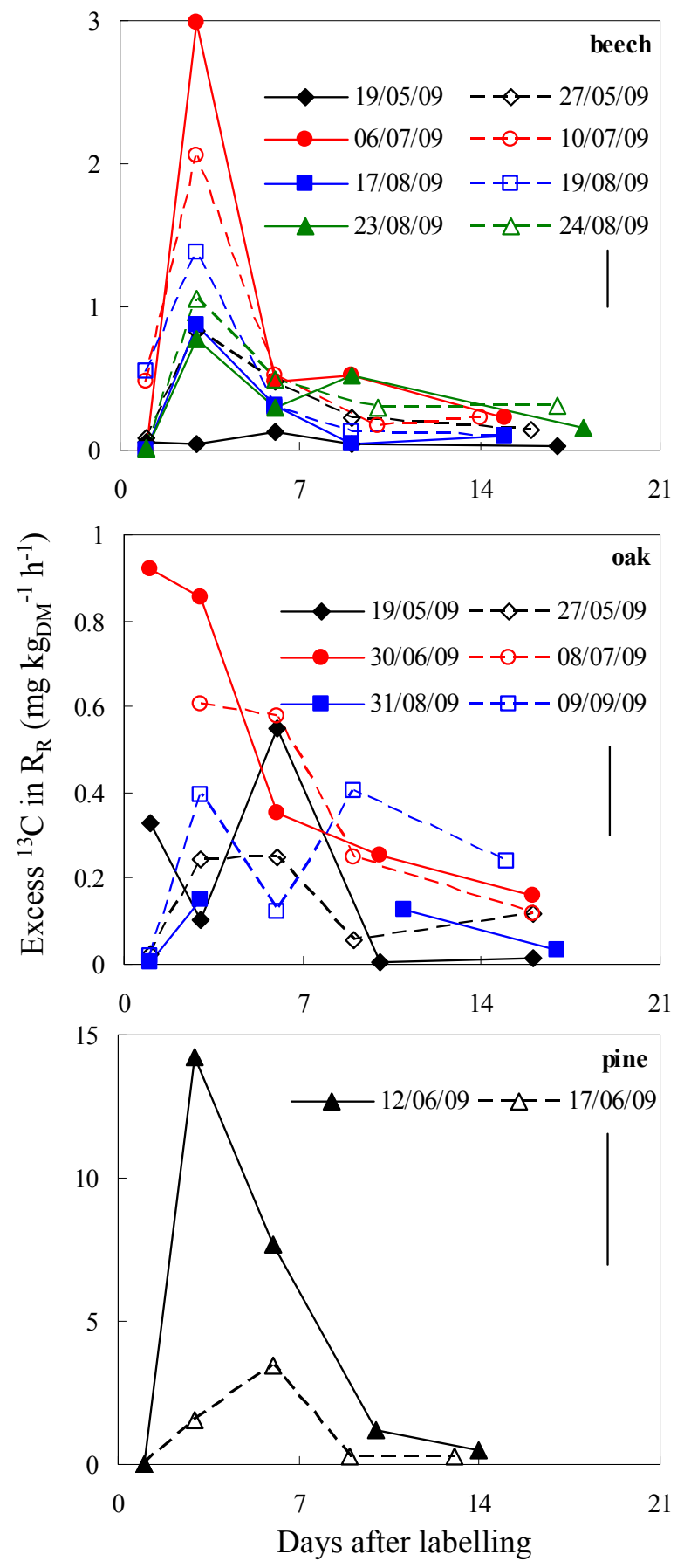

Fig. 4. Time courses of Excess ${ }^{13} \mathrm{C}$ in root respiration $\left(R_{\mathrm{R}}\right)$ after whole crown pulse labelling of beeches (top), oaks (middle) and pines (bottom). Each tree is identified by its date of labelling. There are significant differences between trees for beech $\left(F_{7,42}=4.1, p<\right.$ $0.01)$ and oak $\left(F_{5,15}=3.0, p<0.05\right)$ and between sampling dates for beech $\left(F_{32,42}=4.7, p<0.001\right)$. The verticals bars represent the root mean error.

Biogeosciences, 8, 1153-1168, 2011

\subsection{Amount of carbon allocated to soil $\mathrm{CO}_{2}$ efflux}

It was shown that a simple exponential decay function failed to describe complex kinetics of the label recovered in soil $\mathrm{CO}_{2}$ efflux which was better described by the sum of two exponential functions (Plain et al., 2009). Compartmental models have proven to be an effective and elegant tool to analyse the supply of carbon to root respiration in grass cultivated in quartz sand in a growth cabinet (Lehmeier et al., 2008, 2010a, b). The compartment model (Eq. 9) used to estimate the amount of ${ }^{13} \mathrm{C}$ allocated to soil $\mathrm{CO}_{2}$ efflux assumed that the labelled substrate leaving the crown pool will fill a metabolically active pool that contributes to soil $\mathrm{CO}_{2}$ efflux after a time lag where it can be transferred and back transferred to a metabolically inactive pool. In grass, more than half of respired carbon cycled through a short lived storage pool before being respired (Lehmeier et al., 2008). The situation encountered by trees in the field under fluctuating climatic conditions is much more complex than in the Lehmeier's studies and these two virtual pools have no sound physiological bases. At several occasions, this inactive pool was not required in pine (i.e. the best fit was obtained with $k_{\mathrm{B} 1 \mathrm{~B} 2}=0$ ). A rough estimation of pool size from rate constants (Lehmeier et al., 2010a, supporting information) indicates that both pools were of similar size in beech while the inactive pool was twice the size of the active pool in oak. The model accounted for labelled substrates that are available for root and microbial respiration during the chase period. It does not account for any subsequent mobilisation of stored labelled carbon nor for decomposition of labelled roots, mycelia and microorganisms.

Our experiment highlighted the species specific pattern in the seasonality of the carbon allocation to soil respiration. In pine, a four-times lesser amount of ${ }^{13} \mathrm{C}$ was recovered in soil $\mathrm{CO}_{2}$ efflux after labelling done in November and February compared to those done in June, August and October, indicating that carbon is differently retained in other plant compartments depending on the season. Inhibition of root growth and rhizosphere activity by low soil temperature in late autumn and winter may explain the seasonality of carbon allocation belowground (Kagawa et al., 2006). During the resting season in pine, the amount of ${ }^{13} \mathrm{C}$ allocated to soil $\mathrm{CO}_{2}$ efflux accounted for less than 1-4\% of amount of ${ }^{13} \mathrm{CO}_{2}$ taken up by the crown estimated as the difference between the amount of ${ }^{13} \mathrm{C}$ injected into the labelling chamber and the residual amount of ${ }^{13} \mathrm{CO}_{2}$ in the chamber at the end of the labelling. It raised to 7-10\% during the active growing season, with no strong difference between June, August and October labelling, which contrasts with recent observations on Scots pine (Högberg et al., 2010).

The mild drought imposed by rainfall exclusion did not decrease the contribution of new photosynthates to soil $\mathrm{CO}_{2}$ efflux in contrast to what reported in potted beech saplings (Ruehr et al., 2009). The relative amount of ${ }^{13} \mathrm{C}$ allocated to belowground respiration varied markedly throughout of the 

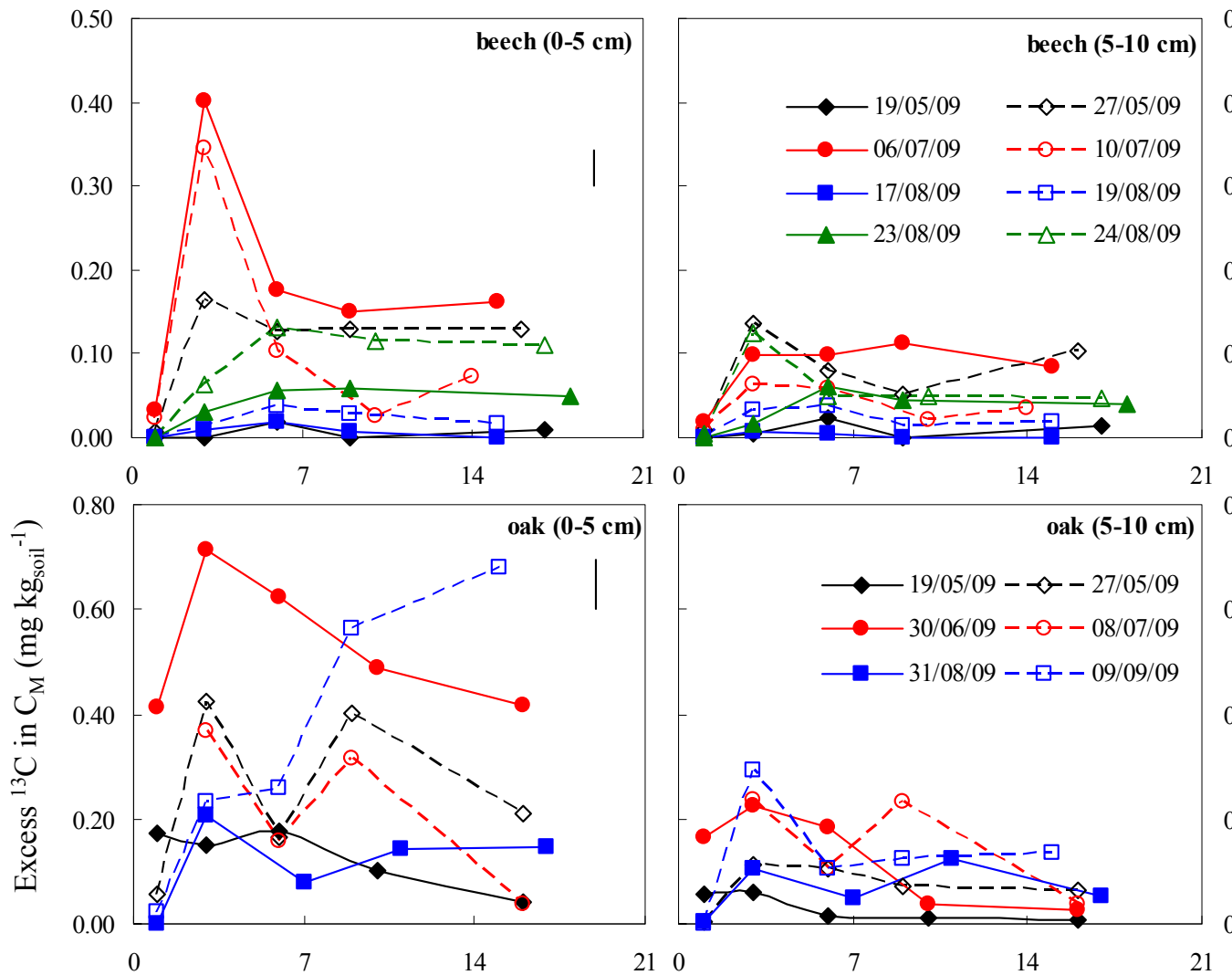

210
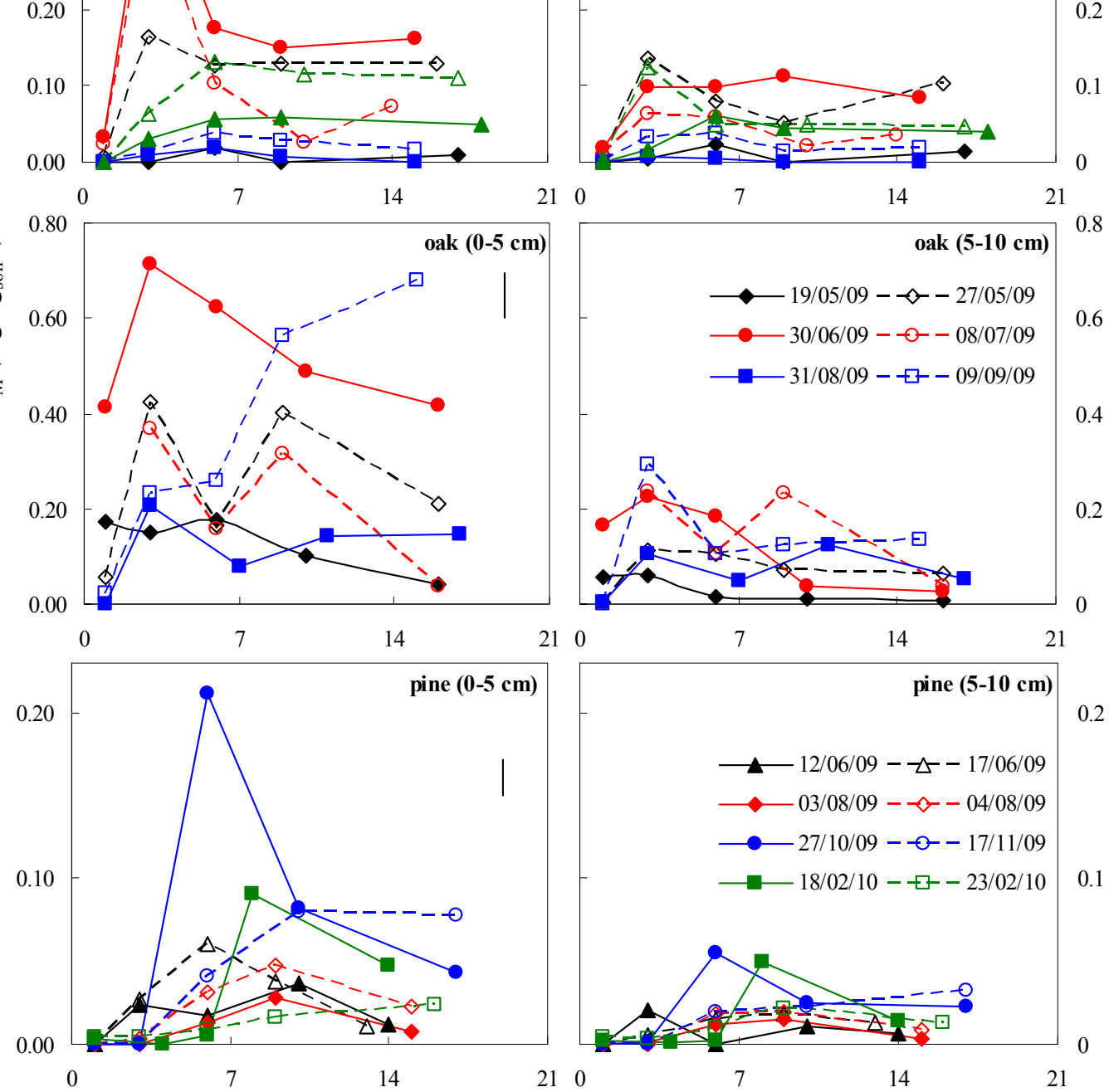

Days after labelling

Fig. 5. Time courses of Excess ${ }^{13} \mathrm{C}$ in microbial carbon $\left(\mathrm{C}_{\mathrm{M}}\right)$ after whole crown pulse labelling of beeches (top), oaks (middle) and pines (bottom) at $0-5 \mathrm{~cm}$ depth (left) and $5-10 \mathrm{~cm}$ depth (right). Data for $10-20 \mathrm{~cm}$ depth in beech and pine are not shown but they are included in the statistical analyses. Each tree is identified by its date of labelling. There are significant differences between trees $\left(F_{7,120}=22.0, F_{5,23}=10.1\right.$ and $F_{7,120}=3.8$, for beech, oak and pine respectively, $\left.p<0.001\right)$, between depth $\left(F_{2,120}=22.0, F_{1,23}=47.1\right.$ and $F_{2,120}=14.5$ for beech, oak and pine respectively, $\left.p<0.001\right)$ and between sampling dates $\left(F_{96,120}=2.5\right.$ for beech, $p<0.001$, $F_{23,23}=2.4$ for oak, $p<0.05$ and $F_{96,120}=3.0$ for pine, $\left.p<0.001\right)$. The verticals bars represent the root mean error. Data are presented on two different panels according to depth but depth was included in the ANOVA.

leafy season with a maximum of $18-21 \%$ of ${ }^{13} \mathrm{C}$ recovered in soil $\mathrm{CO}_{2}$ efflux in July against only $3 \%$ in May and 1$6 \%$ in August. This was also evident from both fine root and microbial respiration, and from both fine root and mi- crobial biomass. This finding agrees well with the high rhizosphere respiration found in early July as inferred from a trenched plot experiment in the same beech forest (Epron et al., 2001). Low allocation of ${ }^{13} \mathrm{C}$ to soil $\mathrm{CO}_{2}$ efflux in May 

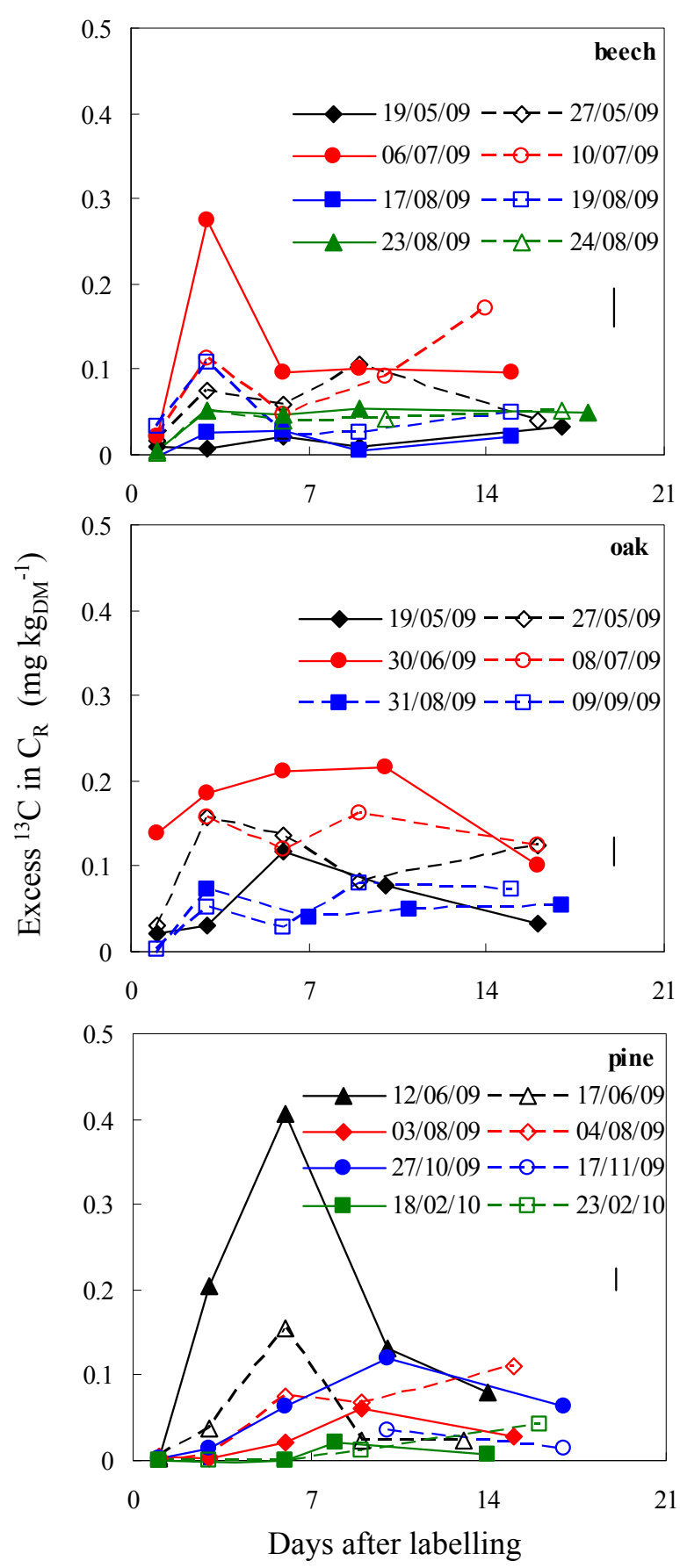

Fig. 6. Time courses of Excess ${ }^{13} \mathrm{C}$ in root carbon $\left(\mathrm{C}_{\mathrm{R}}\right)$ after whole crown pulse labelling of beeches (top), oaks (middle) and pines (bottom). Each tree is identified by its date of labelling. There are significant differences between trees $\left(F_{7,42}=5.9, F_{5,9}=10.7\right.$ and $F_{7,18}=24.1$, for beech, oak and pine respectively, $\left.p<0.001\right)$ and between sampling dates $\left(F_{32,42}=2.0\right.$ and $F_{9,15}=2.69$ for beech and oak respectively, $p<0.05, F_{31,18}=7.4$ for pine, $p<0.001$ ). The verticals bars represent the root mean error. might be related to the sink competition with active aboveground growth that occurs essentially in the few weeks between early May and the end of June. This timing is obvious from leaf phenology observations and recordings of tree diameter growth of this forest stand (Granier et al., 2008). At the end of the growing season until leaf fall, the main carbon sink may be the build-up of storage (Barbaroux et al., 2003) that diverts potentially most carbohydrates resources away from belowground metabolism. In oak, there was low variation in the amount of ${ }^{13} \mathrm{C}$ allocated to soil $\mathrm{CO}_{2}$ efflux among seasons $(7-11 \%)$, which was contrasting with the pattern in beech. This may suggest that stored carbon acts as a buffer between $\mathrm{CO}_{2}$ uptake and $\mathrm{C}$ allocation belowground in this species. Indeed, oak is known to have higher non structural carbohydrate concentration in stem and coarse roots than beech, with also more pronounced seasonal variations in these non structural carbohydrates (Barbaroux et al., 2003).

Despite these differences in the carbon allocation patterns among the three species, we found no difference in residence time of ${ }^{13} \mathrm{C}$ allocated to belowground respiration that averaged 6-7 days during the active growing season. This value is longer than the 4-5 days reported for shrub species (Carbone and Trumbore, 2007), and much more than the $35 \mathrm{~h}$ value reported for small Scots pines (Högberg et al., 2008) but it still represents a fast turnover. In pine, the residence time of ${ }^{13} \mathrm{C}$ allocated to belowground respiration was much higher in November and February, confirming that carbon is retained in other plant compartments during the resting season.

\subsection{C fluxes through root and microbial compartments}

In all species, Excess ${ }^{13} \mathrm{C}$ in $F_{\mathrm{S}}$ was more related to Excess ${ }^{13} \mathrm{C}$ in the root compartment (respiration and biomass) than in the microbial compartment. Root respiration that was measured on excised fine roots retrieved from soil cores might have been affected by wounding (Marsden et al., 2008). Flushes in microbial respiration can occur after sieving, due to aeration and increased substrate for respiration (Achat et al., 2010). Both potentially overestimate and lead to high variability in measured fine root and microbial respiration in the short term, making comparisons with soil $\mathrm{CO}_{2}$ efflux difficult. However, root and microbial respiration seem to be well scaled and observations were repeatable through seasons and between labelled trees. Higher specific fine root respiration in pine compared to beech and oak could not be explained by a higher specific root length since gymnosperm species are known to have thicker fine roots than angiosperm species (Ostonen et al., 2007; Steele et al., 1997). Indeed, reported ranges of specific root lengths for our species in non-fertilized stands were 5.7-31.5 for beech (Ostonen et al., 2007), 7.2-29.1 for oak (Bakker, 1999) and $4-12 \mathrm{mg}^{-1}$ for pine (Bakker et al., 2006). Maritime pine is a fast growing species in contrast to beech and oak, and one fast growing pine species was found to have a higher specific root 

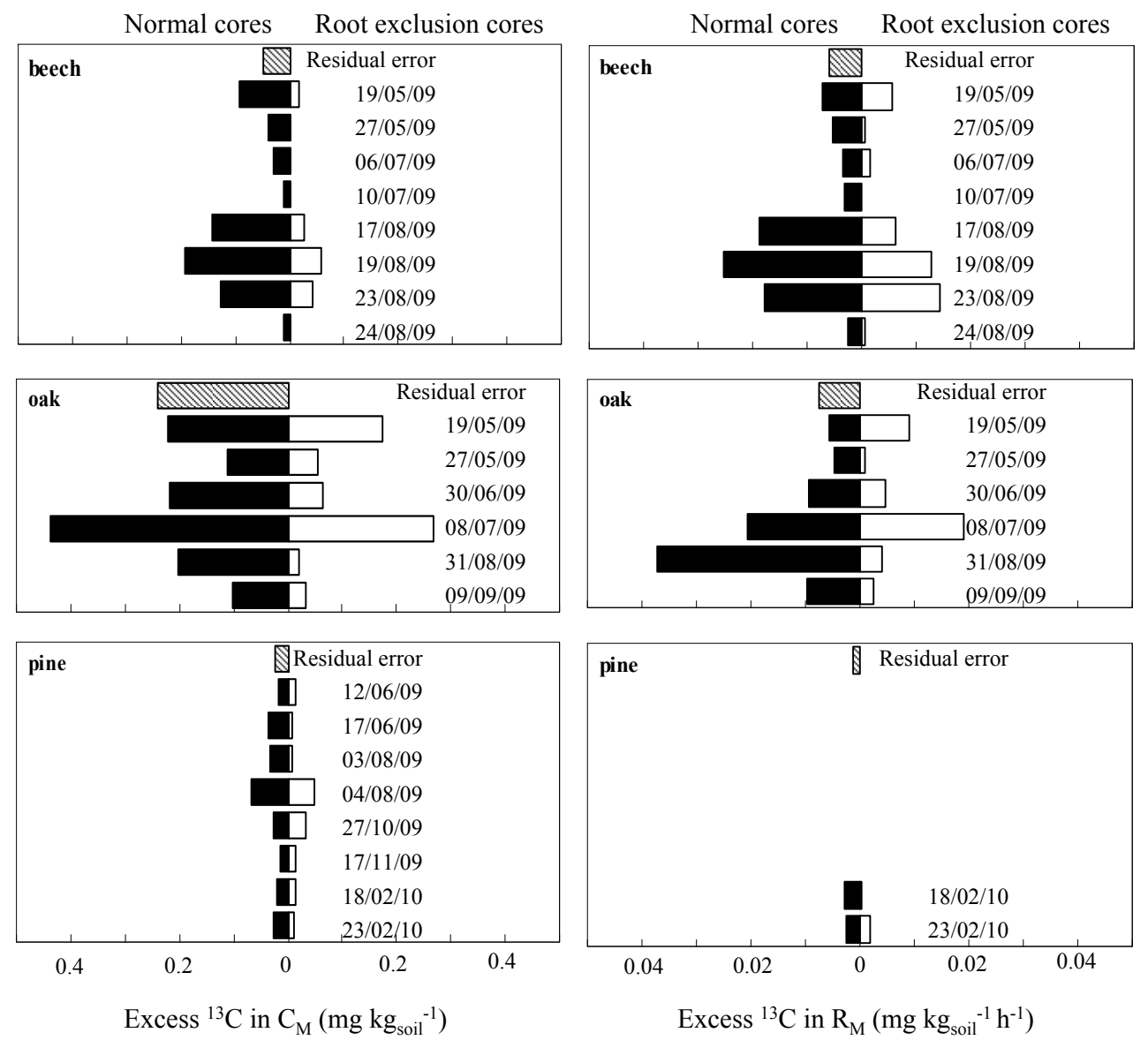

Fig. 7. Excess ${ }^{13} \mathrm{C}$ in microbial carbon $\left(\mathrm{C}_{\mathrm{M}}\right.$, left $)$ or Excess ${ }^{13} \mathrm{C}$ in microbial respiration $\left(R_{\mathrm{M}}\right.$, right $)$ between normal cores and root exclusion cores. Data are pooled by date of sampling and depth for presentation but the statistical analyses were done on non-pooled data. Each tree is identified by its date of labelling. For $\mathrm{C}_{\mathrm{M}}$, there are significant differences for beech and pine between trees $\left(F_{7,64}=7.1\right.$ and $F_{7,64}=8.2$, $p<0.001)$, between depth for beech and oak $\left(F_{1,64}=4.5\right.$ and $F_{1,62}=3.9$ respectively, $\left.p<0.05\right)$ and between sampling dates for beech and pine $\left(F_{32,64}=2.0\right.$ and $\left.F_{32,62}=2.2, p<0.05\right)$. For $R_{\mathrm{M}}$, there are significant differences between trees and between sampling dates for beech $\left(F_{7,63}=10.9\right.$ and $\left.F_{32,63}=3.7, p<0.001\right)$, between depths for all species $\left(F_{1,63}=14.9, F_{1,16}=18.2\right.$ and $F_{1,24}=13.5$ for beech, oak and pine respectively, $p<0.001)$. The dashed bars represent the root mean error.

respiration rate than other slow-growing Pinaceae and Fagaceae species (Comas et al., 2002). Of course, root sorting in not trivial, and we are aware that our root samples could have included different proportion of low-active old roots or even-dead roots depending on the species.

The tracer was recovered at the same time in the fine root and the microbial compartments and peaked after 3 to 6 days, indicating a fast transfer of carbon between roots and microorganisms. Large variability among collected soil samples confounds spatial with temporal variations of Excess ${ }^{13} \mathrm{C}$ in soil compartments, precluding attempts to partition Excess ${ }^{13} \mathrm{C}$ between roots and microbial biomass and to estimate the residence time of carbon within each compartment. Microbial biomass is composed of a large number of different microorganisms and includes the extraradical mycelium of mycorrhizal fungi. A rapid transfer of photosynthate to ectomycorrhiza has indeed been reported (Esperschütz et al.,
2009; Högberg et al., 2010; Leake et al., 2001) and was recently observed from truffle sporocarps after pulse-labelling of chestnut trees (B. Zeller, unpublished data). It has been suggested that a decrease in carbon transfer to microbial biomass can be an early indicator of drought effect on carbon allocation belowground in shrublands (Gorissen et al., 2004). This contrasts with the lack of effect of rainfall exclusion in our experiment in a beech forest. The fact that the Excess ${ }^{13} \mathrm{C}$ in microbial biomass was less in the root exclusion cores than in normal cores indicates that root exudation also contributes to the fast transfer of photosynthates to soil micro-organisms, among which gram negative bacteria that were found to use recent plant derived carbon (Kramer and Gleixner, 2008). However, the Excess ${ }^{13} \mathrm{C}$ in non fumigated soil extracts that would have reflected the dissolved organic carbon released from roots remained very low expect in few oak samples (data not shown). This might be caused by a 
rapid absorption of the released carbon by the bacteria and/or by an important dilution into a large pool of soluble carbon (Esperschütz et al., 2009). Spatial variability of ${ }^{13} \mathrm{C}$ distribution after pulse-labelling is indeed expected at a millimetre scale (Grieve et al., 2006). We didn't attempt to separate bulk soil from root adhering soil where more Excess ${ }^{13} \mathrm{C}$ is expected in the vicinity of the roots both in non fumigated soil extracts and in microbial biomass because of root exudation and rhizodeposition (Esperschütz et al., 2009) and the rhizospheric soil might not be well represented in our fumigated soil extracts.

\section{Conclusions}

Our study has highlighted important seasonal variation in carbon transfer and allocation belowground. Beech appeared to rely more on recent carbon uptake while allocation/mobilisation of stored carbon may damp seasonal variations of carbon allocation belowground in oak. Despite a lower velocity of carbon transfer belowground in pine compared to the two angiosperm species during the active growing season, a similar amount of carbon is allocated to soil $\mathrm{CO}_{2}$ efflux, with a strong seasonal variability. This study highlighted the species specific seasonal pattern of the carbon allocation to fulfil energy requirements of metabolic processes occurring belowground but it failed to confirm any effect of drought on belowground carbon allocation. Additional in situ water manipulation experiments are required to confirm previous results on potted saplings. This study also indicated a fast transfer of photosynthate to the microbial biomass including mycorrhizal mycelia and microorganisms feeding on root exudates. However, further analyses will be needed to better describe the fate of carbon in the complex soil microbial community, a prerequisite for improving our understanding of soil carbon dynamics in forest ecosystems and their contribution to the global carbon cycle.

Acknowledgements. Financial support was provided by the French National Research Agency (ANR) through the CATS Project (ANR-07-BLAN-0109). The CATS labelling experimentation was a team work and the authors would like to thank all persons taking part in it. Authors also acknowledge the "MétabolismeMétabolome" platform of the IFR87 and the "functional ecology" platform of the IFR 110 for IRMS analyses.

Edited by: M. Bahn

\section{References}

Achat, D. L., Morel, C., Bakker, M. R., Augusto, L., Pellerin, S., Gallet-Budynek, A., and Gonzalez, M.: Assessing turnover of microbial biomass phosphorus: Combination of an isotopic dilution method with a mass balance model, Soil Biol. Biochem., 42, 2231-2240, 2010.
Bahn, M., Schmitt, M., Siegwolf, R., Richter, A., and Brüggemann, N.: Does photosynthesis affect grassland soil-respired $\mathrm{CO}_{2}$ and its carbon isotope composition on a diurnal timescale?, New Phytol., 182, 451-460, 2009.

Bahn, M., Reichstein, M., Davidson, E. A., Grünzweig, J., Jung, M., Carbone, M. S., Epron, D., Misson, L., Nouvellon, Y., Roupsard, O., Savage, K., Trumbore, S. E., Gimeno, C., Curiel Yuste, J., Tang, J., Vargas, R., and Janssens, I. A.: Soil respiration at mean annual temperature predicts annual total across vegetation types and biomes, Biogeosciences, 7, 2147-2157, doi:10.5194/bg-7-2147-2010, 2010.

Bakker, M. R.: The effects of liming and gypsum applications on a sessile oak (Quercus petraea (M.) Liebl.) stand at La CroixScaille (French Ardennes) II. Fine root dynamics, Plant Soil, 206, 109-121, 1999.

Bakker, M. R., Augusto, L., and Achat, D.: Fine root distribution of trees and understory in mature stands of maritime pine (Pinus pinaster) on dry and humid sites, Plant Soil, 286, 37-51, 2006.

Barbaroux, C. and Bréda, N.: Contrasting distribution and seasonal dynamics of carbohydrate reserves in stem wood of adult ringporous sessile oak and diffuse-porous beech trees, Tree Physiol., 22, 1201-1210, 2002.

Barbaroux, C., Bréda, N., and Dufrêne, E.: Distribution of aboveground and below-ground carbohydrate reserves in adult trees of two contrasting broad-leaved species (Quercus petraea and Fagus sylvatica), New Phytol., 157, 605-615, 2003.

Bowling, D. R., McDowell, N. G., Bond, B. J., Law, B. E., and Ehleringer, J. R.: ${ }^{13} \mathrm{C}$ content of ecosystem respiration is linked to precipitation and vapor pressure deficit, Oecologia, 131, 113124, 2002.

Bowling, D. R., Pataki, D. E., and Randerson, J. T.: Carbon isotopes in terrestrial ecosystem pools and $\mathrm{CO}_{2}$ fluxes, New Phytol., 178, 24-40, 2008.

Bréda, N. and Granier, A.: Intra- and interannual variations of transpiration, leaf area index and radial growth of a sessile oak stand (Quercus petraea), Ann. For. Sci., 53, 521-536, 1996.

Carbone, M. S. and Trumbore, S. E.: Contribution of new photosynthetic assimilates to respiration by perennial grasses and shrubs: residence times and allocation patterns, New Phytol., 176, 124135, 2007.

Carbone, M. S., Czimczik, C. I., McDuffee, K. E., and Trumbore, S. E.: Allocation and residence time of photosynthetic products in a boreal forest using a low-level ${ }^{14} \mathrm{C}$ pulse-chase labeling technique, Glob. Change Biol., 13, 466-477, 2007.

Comas, L. H., Bouma, T. J., and Eissenstat, D. M.: Linking root traits to potential growth rate in six temperate tree species, Oecologia, 132, 34-43, 2002.

Coplen, T. B., Böhlke, J. K., De Bièvre, P., Ding, T., Holden, N. E., Hopple, J. A., Krouse, H. R., Lamberty, A., Peiser, H. S., Révész, K., Rieder, S. E., Rosman, K. J. R., Roth, E., Taylor, P. D. P., Vocke, R. D. J., and Xiao, Y. K.: Isotope-abundance variations of selected elements, Pure Applied Chemistry, 74, 1987-2017, 2002.

Craine, J. M., Wedin, D. A., and Chapin III., F. S.: Predominance of ecophysiological controls on soil $\mathrm{CO}_{2}$ flux in a Minnesota grassland, Plant Soil, 207, 77-86, 1999.

Dannoura, M., Maillard, P., Fresneau, C., Plain, C., Berveiller, D., Gérant, D., Chipeaux, C., Bosc, A., Ngao, J., Damesin, C., Loustau, D., and Epron, D.: In situ assessment of the velocity of 
carbon transfer by tracing ${ }^{13} \mathrm{C}$ in trunk $\mathrm{CO}_{2}$ efflux after pulse labelling: variations among tree species and season, New Phytol., 190, 181-192, 2011.

Ekblad, A., Boström, B., Holm, A., and Comstedt, D.: Forest soil respiration rate and $\delta^{13} \mathrm{C}$ is regulated by recent above ground weather conditions, Oecologia, 143, 136-142, 2005.

Epron, D.: Chapter 8: Separating autotrophic and heterotrophic components of soil respiration: lessons learned from trenching and related root exclusion experiments, in: Soil Carbon Flux Measurements. An Integrated Methodology, edited by: Kutsch, W., Bahn, M., and Heinemeyer, A., Cambridge University Press, 562-602, 2009.

Epron, D., Farque, L., Lucot, E., and Badot, P. M.: Soil $\mathrm{CO}_{2}$ efflux in a beech forest: dependence on soil temperature and soil water content, Ann. For. Sci., 56, 221-226, 1999.

Epron, D., Le Dantec, V., Dufrêne, E., and Granier, A.: Seasonal dynamics of soil carbon dioxide efflux and simulated rhizosphere respiration in a beech forest, Tree Physiol., 21, 145-152, 2001.

Esperschütz, J., Buegger, F., Winkler, J. B., Munch, J. C., Schloter, M., and Gattinger, A.: Microbial response to exudates in the rhizosphere of young beech trees (Fagus sylvatica $\mathrm{L}$.) after dormancy, Soil Biol. Biochem., 41, 1976-1985, 2009.

Gaumont-Guay, D., Black, T. A., Barr, A. G., Jassal, R. S., and Nesic, Z.: Biophysical controls on rhizospheric and heterotrophic components of soil respiration in a boreal black spruce stand, Tree Physiol., 28, 161-171, 2008.

Giardina, C. P. and Ryan, M. G.: Total belowground carbon allocation in a fast-growing Eucalyptus plantation estimated using a carbon balance approach, Ecosystems, 5, 487-499, 2002.

Gorissen, A., Tietema, A., Joosten, N. N., Estiarte, M., Peñuelas, J., Sowerby, A., Emmett, B. A., and Beier, C.: Climate change affects carbon allocation to the soil in shrublands, Ecosystems, 7, 650-661, 2004.

Granier, A., Bréda, N., Longdoz, B., Gross, P., and Ngao, J.: Ten years of fluxes and stand growth in a young beech forest at Hesse, North-eastern France, Ann. For. Sci., 65, 704, doi:10.1051/forest:2008052, 2008.

Grieve, I. C., Davidson, D. A., Ostle, N. J., Bruneau, P. M. C., and Fallick, A. E.: Spatial heterogeneity in the relocation of added ${ }^{13} \mathrm{C}$ within the structure of an upland grassland soil, Soil Biol. Biochem., 38, 229-234, 2006.

Griffis, T. J., Baker, J. M., Sargent, S. D., Tanner, B. D., and Zhang, J.: Measuring field-scale isotopic $\mathrm{CO}_{2}$ fluxes with tunable diode laser absorption spectroscopy and micrometeorological techniques, Agr. Forest Meteorol., 124, 15-29, 2004.

Högberg, M. N., Briones, M. J. I., Keel, S. G., Metcalfe, D. B., Campbell, C., Midwood, A. J., Thornton, B., Hurry, V., Linder, S., Näsholm, T., and Högberg, P.: Quantification of effects of season and nitrogen supply on tree below-ground carbon transfer to ectomycorrhizal fungi and other soil organisms in a boreal pine forest, New Phytol., 187, 485-493, 2010.

Högberg, P. and Read, D. J.: Towards a more plant physiological perspective on soil ecology, Trends Ecol. Evol., 21, 549-554, 2006.

Högberg, P., Högberg, M. N., Gottlicher, S. G., Betson, N. R., Keel, S. G., Metcalfe, D. B., Campbell, C., Schindlbacher, A., Hurry, V., Lundmark, T., Linder, S., and Nasholm, T.: High temporal resolution tracing of photosynthate carbon from the tree canopy to forest soil microorganisms, New Phytol., 177, 220-228, 2008.
Hölttä, T., Mencuccini, M., and Nikinmaa, E.: Linking phloem function to structure: Analysis with a coupled xylem-phloem transport model, J. Theor. Biol., 259, 325-337, 2009.

Horwath, W. R., Pregitzer, K. S., and Paul, E. A.: ${ }^{14}$ C Allocation in tree-soil systems, Tree Physiol., 14, 1163-1176, 1994.

Janssens, I. A., Lankreijer, H., Metteucci, G., Kowalski, A. S., Buchmann, N., Epron, D., Pilegaard, K., Kutsch, W., Longdoz, B., Grünwald, T., Montagnani, L., Dore, S., Rebmann, C., Moors, E. J., Grelle, A., Rannik, Ü., Morgenstern, K., Oltchev, S., Clement, R., Gudmundsson, J., Minerbi, S., Berbigier, P., Ibrom, A., Moncrieff, J., Aubinet, M., Bernhofer, C., Jensen, N. O., Vesala, T., Granier, A., Schulze, E.-D., Lindroth, A., Dolman, A. J., Jarvis, P. G., Ceulemans, R., and Valentini, R.: Productivity overshadows temperature in determining soil and ecosystem respiration across European forests, Glob. Change Biol., 7, 269278, 2001.

Kagawa, A., Sugimoto, A., and Maximov, T. C.: Seasonal course of translocation, storage and remobilization of ${ }^{13} \mathrm{C}$ pulse-labeled photoassimilate in naturally growing Larix gmelinii saplings, New Phytol., 171, 793-804, 2006.

Körner, C.: Carbon limitation in trees, J. Ecol., 91, 4-17, 2003.

Kramer, C. and Gleixner, G.: Soil organic matter in soil depth profiles: Distinct carbon preferences of microbial groups during carbon transformation, Soil Biol. Biochem., 40, 425-433, 2008.

Kuptz, D., Fleischmann, F., Matyssek, R., and Grams, T. E. E.: Seasonal patterns of carbon allocation to respiratory pools in 60yr-old deciduous (Fagus sylvatica) and evergreen (Picea abies) trees assessed via whole-tree stable carbon isotope labeling, New Phytol., 10.1111/j.1469-8137.2011.03676.x, in press, 2011.

Kuzyakov, Y. and Gavrichkova, O.: Time lag between photosynthesis and $\mathrm{CO}_{2}$ efflux from soil: A review of mechanisms and controls, Glob. Change Biol., 16, 3386-3406, 2010.

Lattanzi, F. A., Schnyder, H., and Thornton, B.: The sources of carbon and nitrogen supplying leaf growth. Assessment of the role of stores with compartmental models, Plant Physiol., 137, 383-395, 2005.

Leake, J. R., Donnelly, D. P., Saunders, E. M., Boddy, L., and Read, D. J.: Rates and quantities of carbon flux to ectomycorrhizal mycelium following ${ }^{14} \mathrm{C}$ pulse labeling of Pinus sylvestris seedlings: effects of litter patches and interaction with a wooddecomposer fungus, Tree Physiol., 21, 71-82, 2001.

Lehmeier, C. A., Lattanzi, F. A., Schaufele, R., Wild, M., and Schnyder, H.: Root and shoot respiration of perennial ryegrass are supplied by the same substrate pools: assessment by dynamic ${ }^{13} \mathrm{C}$ labeling and compartmental analysis of tracer kinetics, Plant Physiol., 148, 1148-1158, 2008.

Lehmeier, C. A., Lattanzi, F. A., Gamnitzer, U., Schäufele, R., and Schnyder, H.: Day-length effects on carbon stores for respiration of perennial ryegrass, New Phytol., 188, 719-725, 2010a.

Lehmeier, C. A., Lattanzi, F. A., Schäufele, R., and Schnyder, H.: Nitrogen deficiency increases the residence time of respiratory carbon in the respiratory substrate supply system of perennial ryegrass, Plant Cell Environ., 33, 76-87, 2010 b.

Litton, C. M., Raich, J. W., and Ryan, M. G.: Carbon allocation in forest ecosystems, Glob. Change Biol., 13, 2089-2109, 2007.

Litton, C. M. and Giardina, C. P.: Below-ground carbon flux and partitioning: global patterns and response to temperature, Funct. Ecol., 22, 941-954, 2008.

Marron, N., Plain, C., Longdoz, B., and Epron, D.: Seasonal and 
daily time course of the ${ }^{13} \mathrm{C}$ composition in soil $\mathrm{CO}_{2}$ efflux recorded with a tunable diode laser spectrophotometer (TDLS), Plant Soil, 318, 137-151, 2009.

Marsden, C., Nouvellon, Y., and Epron, D.: Relating coarse root respiration to root diameter in clonal Eucalyptus stands in the Republic of the Congo, Tree Physiol., 28, 1245-1254, 2008.

McDowell, N. G., Bowling, D. R., Schauer, A., Irvine, J., Bond, B. J., Law, B. E., and Ehleringer, J. R.: Associations between carbon isotope ratios of ecosystem respiration, water availability and canopy conductance, Glob. Change Biol., 10, 1767-1784, 2004.

Mencuccini, M. and Hölttä, T.: The significance of phloem transport for the speed with which canopy photosynthesis and belowground respiration are linked, New Phytol., 185, 189-203, 2010.

Mikan, C. J., Zak, D. R., Kubiske, M. E., and Pregitzer, K. S.: Combined effects of atmospheric $\mathrm{CO}_{2}$ and $\mathrm{N}$ availability on the belowground carbon and nitrogen dynamics of aspen mesocosms, Oecologia, 124, 432-445, 2000.

Mortazavi, B., Chanton, J. P., Prater, J. L., Oishi, A. C., Oren, R., and Katul, G.: Temporal variability in ${ }^{13} \mathrm{C}$ of respired $\mathrm{CO}_{2}$ in a pine and a hardwood forest subject to similar climatic conditions, Oecologia, 142, 57-69, 2005.

Ostonen, I., Püttsepp, Ü., Biel, C., Alberton, O., Bakker, M. R., Lõhmus, K., Majdi, H., Metcalfe, D., Olsthoorn, A. F. M., Pronk, A., Vanguelova, E., Weih, M., and Brunner, I.: Specific root length as an indicator of environmental change, Plant Biosyst., 141, 426-442, 2007.

Peuke, A. D., Windt, C., and Van As, H.: Effects of cold-girdling on flows in the transport phloem in Ricinus communis: is mass flow inhibited?, Plant Cell Environ., 29, 15-25, 2006.

Plain, C., Gérant, D., Maillard, P., Dannoura, M., Dong, Y., Zeller, B., Priault, P., Parent, F., and Epron, D.: Tracing of recently assimilated carbon in respiration at high temporal resolution in the field with a tuneable diode laser absorption spectrometer after in situ ${ }^{13} \mathrm{CO}_{2}$ pulse labelling of 20 -year-old beech trees, Tree Physiol., 29, 1433-1447, 2009.

Pumpanen, J., Heinonsalo, J., Rasilo, T., Hurme, K.-R., and Ilvesniemi, H.: Carbon balance and allocation of assimilated $\mathrm{CO}_{2}$ in Scots pine, Norway spruce, and Silver birch seedlings determined with gas exchange measurements and ${ }^{14} \mathrm{C}$ pulse labelling, Trees-Struct. Funct., 23, 611-621, 2009.
Raich, J. W., Potter, C. S., and Bhagawati, D.: Interannual variability in global soil respiration, 1980-94, Glob. Change Biol., 8, 800-812, 2002.

Ruehr, N. K., Offermann, C. A., Gessler, A., Winkler, J. B., Ferrio, J. P., Buchmann, N., and Barnard, R. L.: Drought effects on allocation of recent carbon: from beech leaves to soil $\mathrm{CO}_{2}$ efflux, New Phytol., 184, 950-961, 2009.

Ryan, M. G. and Law, B. E.: Interpreting, measuring, and modelling soil respiration, Biogeochemistry, 73, 3-27, 2005.

Steele, S. J., Gower, S. T., Vogel, J. G., and Norman, J. M.: Root mass, net primary production and turnover in aspen, jack pine and black spruce forests in Saskatchewan and Manitoba, Canada, Tree Physiol., 17, 577-587, 1997.

Stoy, P. C., Palmroth, S., Oishi, A. C., Siqueira, M. B. S., Juang, J.-Y., Novick, K. A., Ward, E. J., Katul, G. G., and Oren, R.: Are ecosystem carbon inputs and outputs coupled at short time scales? A case study from adjacent pine and hardwood forests using impulse-response analysis, Plant Cell Environ., 30, 700710, 2007.

Subke, J.-A., Inglima, I., and Cotrufo, M. F.: Trends and methodological impacts in soil $\mathrm{CO}_{2}$ efflux partitioning: A metaanalytical review, Glob. Change Biol., 12, 921-943, 2006.

Subke, J.-A., Vallack, H. W., Tord, M., Keel, S. G., Metcalfe, D. B., Högberg, P., and Ineson, P.: Short-term dynamics of abiotic and biotic soil ${ }^{13} \mathrm{CO}_{2}$ effluxes after in situ ${ }^{13} \mathrm{CO}_{2}$ pulse labelling of a boreal pine forest, New Phytol., 183, 349-357, 2009.

Tang, J., Baldocchi, D. D., and Xu, L.: Tree photosynthesis modulates soil respiration on a diurnal time scale., Glob. Change Biol., 11, 1298-1304, 2005.

Trumbore, S.: Carbon respired by terrestrial ecosystems - recent progress and challenges, Glob. Change Biol., 12, 141-153, 2006.

Vance, E. D., Brookes, P. C., and Jenkinson, D. S.: An extraction method for measuring soil microbial biomass C, Soil Biol. Biochem., 19, 703-707, 1987.

Wingate, L., Ogée, J., Burlett, R., Bosc, A., Devaux, M., Grace, J., Loustau, D., and Gessler, A.: Photosynthetic carbon isotope discrimination and its relationship to the carbon isotope signals of stem, soil and ecosystem respiration, New Phytol., 188, 576589, 2010. 